Georgia State University

ScholarWorks @ Georgia State University

Computer Information Systems Faculty

Publications

Department of Computer Information Systems

3-2009

\title{
Interfirm IT Capability Profiles and Communications for Cocreating Relational Value: Evidence from the Logistics Industry
}

Arun Rai

Georgia State University, arunrai@gsu.edu

Paul Pavlou

Temple University, pavlou@temple.edu

Ghiyoung Im

University of Louisville, ghiyoung@gmail.com

Steve Du

Georgia State University, steve.du@zoho.com

Follow this and additional works at: https://scholarworks.gsu.edu/cis_facpub

Part of the Management Information Systems Commons

\section{Recommended Citation}

Rai, A., Pavlou, P., Im, G., and Du. S., Interfirm IT Capabilities and Communications for Co- Creating Relational Value: Evidence from the Logistics Industry, MIS Quarterly, 2012, 36(1), 233-262.

http://misq.org/interfirm-it-capability-profiles-and-communications-for-cocreating-relational-valueevidence-from-the-logistics-industry.html.

This Article is brought to you for free and open access by the Department of Computer Information Systems at ScholarWorks @ Georgia State University. It has been accepted for inclusion in Computer Information Systems Faculty Publications by an authorized administrator of ScholarWorks @ Georgia State University. For more information, please contact scholarworks@gsu.edu. 


\title{
INTERFIRM IT CAPABILITY PROFILES AND COMMUNICATIONS FOR COCREATING RELATIONAL VALUE: EVIDENCE FROM THE LOGISTICS INDUSTRY ${ }^{1}$
}

\author{
Arun Rai \\ Center for Process Innovation and Department of Computer Information Systems, Robinson College of Business, \\ Georgia State University, Atlanta, GA 30303 U.S.A. \{arunrai@gsu.edu\} \\ Paul A. Pavlou \\ Fox School of Business, Temple University, Philadelphia, PA 19122 U.S.A. \{pavlou@temple.edu\} \\ Ghiyoung Im \\ Computer Information Systems, College of Business, University of Louisville, \\ Louisville, KY 40292 U.S.A. \{ghiyoung@gmail.com\} \\ Steve Du \\ Center for Process Innovation, Robinson College of Business, Georgia State University, \\ Atlanta, GA 30303 U.S.A. \{steve.du@zoho.com\}
}

\begin{abstract}
This study seeks to identify the means by which information technology helps cocreate relational value in the context of interfirm relationships in the logistics industry - a large and information-intensive industry. We identify a set of IT functionalities-single-location shipping, multilocation shipping, supply chain visibility, and financial settlement - that can be used to manage the flows of physical goods, information, and finances across locations in interfirm logistics processes. Progressively more advanced sets of IT functionalities, when implemented and used in the interfirm relationship to execute logistics processes, are proposed to form four distinct IT capability profiles of increased sophistication. Interfirm IT capability profiles of higher sophistication are proposed to help cocreate greater relational value by facilitating the flows of physical goods, information, and finances across locations in the interfirm logistics process. Besides their direct role in helping cocreate relational value, these interfirm IT capability profiles are proposed to further enhance relational value cocreation when complemented by interfirm communications for business development and IT development.
\end{abstract}

Our empirical study was situated in one of the world's largest logistics suppliers and over 2,000 of its interfirm relationships with buyers across industries. Integrated data from four archival sources on the IT functionalities implemented and used in interfirm logistics relationships, interfirm communications, relational value (share of wallet and loyalty), and multiple control variables were collected. The results show that the proposed interfirm IT capability profiles and interfirm communications have both a direct and an interaction effect on relational value. Implications for cocreating relational value in interfirm relationships with the aid of IT are discussed.

Keywords: Relational value, relational view, share of wallet, interfirm relationships, IT capability profiles, IT functionalities, contact streams, interfirm communications, complementarities, logistics

\footnotetext{
${ }^{1}$ Varun Grover and Rajiv Kohli were the accepting senior editors for this paper. Indranil Bardhan served as the associate editor.

The appendices for this paper are located in the "Online Supplements" section of the MIS Quarterly's website (http://www.misq.org).
} 


\section{Introduction}

Relational value is defined as mutual benefits that are jointly cocreated by two or more firms (Dyer and Singh 1998). Firms often establish interfirm relationships to cocreate relational value that cannot be created on their own or through market exchanges. These interfirm relationships are established to share costs and production facilities, promote innovation, develop new products, manage complex processes across locations, and access new markets, technologies, and resources (Bensaou 1997; Choudhury and Sabherwal 2003; Gulati and Singh 1998). To achieve these goals, firms adopt a "cooperative logic" and move toward strategic relationships (Kale et al. 2002; Koza and Lewin 1998; Lorange and Roos 1993; Mowery et al. 1996), interfirm collaboration (Bensaou 1997; Cannon and Perreault 1999; Dwyer et al. 1987; Dyer 2000; Jap 2001; Morgan and Hunt 1994; Powell et al. 1996), and value-adding partnerships (Holm et al. 1999; Primo and Amundson 2002; Zajac and Olsen 1993). For example, Hewlett Packard (HP) and United Parcel Service (UPS) developed an interfirm logistics relationship that was able to cocreate substantial relational value over time (arguably above what was reasonably expected from an arm's-length market exchange), thereby leading UPS to gain a larger portion of HP's share of wallet for logistics (Lewis et al. 2007).

The relational view (Dyer and Singh 1998) is a major theoretical perspective on how interfirm relationships can cocreate relational value. Based on the relational view, recent IS studies have examined the role of IT resources as determinants of relational value. Empirical evidence suggests that relationship-specific IT investments enable partners to share idiosyncratic information that can be leveraged in their interfirm relationship to help cocreate relational value (e.g., Klein and Rai 2009; Saraf et al. 2007; Subramani 2004). Recent IS studies have also shown that an improved IT-enabled coordination of interfirm processes enables partnering firms to enhance their performance (Bharadwaj et al. 2007; Sambamurthy et al. 2003). However, we still have a limited understanding on the characteristics of interfirm IT capabilities and the communication routines for sharing information that enable firms to cocreate relational value (Klein and Rai 2009).

Anecdotal evidence from practice suggests that interfirm IT capabilities and communications between partners are pivotal to cocreating value from interfirm business processes. As an example, the HP-UPS relationship has developed a sophisticated profile of interfirm IT capabilities to synchronize the flow of physical goods, information, and finances across locations in their globally distributed logistics processes, facilitating relational value cocreation. Relational value is evidenced by decreased transportation and inventory costs, reduced stock-outs, and enhanced market response that reach value levels above those that could be obtained by an arm'slength market exchange. The HP-UPS relationship has established routines for key personnel dedicated to the relationship to communicate both for business development (e.g., to understand the complex interdependencies in the logistics process, inform each other about current and projected logistics capabilities, and jointly evaluate opportunities for value cocreation) and IT development (e.g., to understand IT needs for the interfirm logistics process, inform the buyer about the supplier's evolving IT functionalities and support services, learn about the buyer's evolving IT infrastructure, and discuss how IT functionalities can be implemented better and used to support the interfirm logistics process). Therefore, there is practical evidence that interfirm IT capabilities and communications can help build relational value.

We identify a set of four key IT functionalities (singlelocation shipping, multilocation shipping, supply chain visibility, and financial settlement) that have been designed to help manage the flows of physical goods, information, and finances in interfirm logistics processes. We explain how the implementation and use of these progressively more advanced sets of IT functionalities help develop four corresponding interfirm IT capability profiles of increased sophistication, which, in turn, create greater relational value by facilitating the flows of physical goods, information, and finances in the interfirm logistics process. Interfirm IT capability profiles are defined as groupings of interfirm relationships that implement and use a set of IT functionalities to execute interfirm business processes. Furthermore, we examine the direct effects of interfirm communications related to business development and IT development on cocreating relational value besides their interactive effects with the IT capability profiles. Indeed, the literature on IT business value and the call for papers for this special issue stress the need to enhance our understanding of how interfirm IT capabilities supported by other interfirm activities, such as interfirm communications, help cocreate relational value.

Our overarching objective is to enhance our understanding of how interfirm IT capability profiles and interfirm communications can help cocreate relational value in interfirm relationships by addressing three research questions: (1) How do IT capability profiles enable interfirm relationships to cocreate relational value? (2) How do interfirm communications for business and IT development enable interfirm relationships to cocreate relational value? (3) How do the proposed interfirm IT capability profiles interact with interfirm communications to jointly cocreate relational value?

Our empirical study in the context of the logistics industry is based on multiple sources of archival data of interfirm relationships between one of the world's largest logistics sup- 
pliers and over 2,000 of its buyers that have established an ongoing interfirm relationship. As such, these logistics relationships are governed by similar contractual specifications with the primary variations being in the interfirm IT capability profiles and the extent of interfirm communications. Relational value is captured with two success outcomes of interfirm relationhsips: share of wallet and loyalty. Share of wallet reflects the percentage of money a buyer allocates to the supplier, while loyalty captures the buyer's commitment to selecting the supplier in the future (Cooil et al. 2007).

Our results suggest that sophisticated interfirm IT capability profiles, formed by implementing and using advanced sets of IT functionalities, coupled with interfirm communications on business and IT development lead buyers to allocate a greater share of their wallet to a supplier and to increased buyer loyalty toward the supplier. This study contributes to enhancing our understanding of relational value cocreation by showing how interfirm IT capability profiles and communications-both individually and jointly-help cocreate relational value in interfirm relationships.

The paper proceeds as follows: The next section gives a brief overview of the logistics industry, which is the study's investigative context. The subsequent section introduces the theory development. The following sections describe the research method, present the study's results, and discuss the study's implications.

\section{Investigative Context}

We developed our research model, justified our hypotheses, and conducted our empirical study in the context of interfirm relationships in the logistics industry. This is well aligned with our objectives for four key reasons. First, the logistics industry is particularly information intensive, and it has seen significant IT investments and rapid-fire IT innovations to manage complex interdependencies in the flow of physical goods, information, and logistics across shipping locations to create relational value (Klein et al. 2007). Logistics processes offer opportunities for IT-enabled value cocreation because interdependencies in logistics activities are often not managed well, leading to cost inefficiencies, lost market opportunities, and lower satisfaction with interfirm logistics relationships (IBM Research 2004; Rai and Sambamurthy 2006). Second, joint logistics processes (e.g., inventory management, new product introduction) are vital for value cocreation for both manufacturing and service firms throughout the product life cycle (Simchi-Levi et al. 2008). Third, given the capitalintensive assets (including interfirm IT functionalities) often required in logistics processes and the high depreciation of these assets (e.g., IT systems), there has been a significant growth in interfirm relationships (e.g., Klein and Rai 2009). Finally, logistics is one of the largest industries in the United States, making it an ideal context to better understand the mechanisms by which IT contributes to value cocreation.

We operationalize our constructs (i.e., interfirm IT capability profiles, interfirm communications, and relational value) in the context of interfirm buyer-supplier relationships in the logistics industry. Our unit of analysis is the relationship between a buyer and a supplier (logistics provider) in which the buyer sources its logistics needs to a supplier to manage its logistics suppy chain. ${ }^{2}$ By capturing the key constructs of interfirm relationships in the logistics industry, we seek to propose that these three constructs have a significant role in relational value cocreation. Generalizing these constructs from the logistics industry to other industries may be theoretically feasible given the generalizable nature of the key constructs (interfirm IT capability profiles, interfirm communications, and relational value).

\section{Theory Development}

\section{The Relational View}

Dyer and Singh's (1998, p. 675) relational view sees buyers growing "profits by increasing their dependence on a smaller number of suppliers, thereby increasing the suppliers' incentives to share knowledge and make performanceenhancing investments." Dyer and Singh explain that increased dependence motivates firms to share more information with other firms, make relationship-specific investments, and build stronger interfirm capabilities to create relational value. The relational view is consistent with a major directional change in interfirm relationships from market-like arm's length exchanges to relational contracting (MacNeil 1980), working partnerships (Anderson and Narus 1984), trust-based relationships (Doney and Cannon 1997; Ganesan 1994; Morgan and Hunt 1994), research and development collaborations, cross-licensing agreements, equity sharing arrangements, and joint ventures (Bensaou and Venkatraman 1995; Dyer 1997; Dyer 2000; Gulati and Singh 1998; Kanter 1994; Lane and Lubatkin 1998). This view is also consistent with Bakos and Brynjolfsson's (1993, p. 43) contention that buyers who pursue greater dependence on fewer suppliers provide incentives to suppliers to make "investments in innovation, responsiveness, and information sharing."

\footnotetext{
${ }^{2}$ However, our unit of analysis is not the buyer's supply chain, which can include several other partners and relationships.
} 


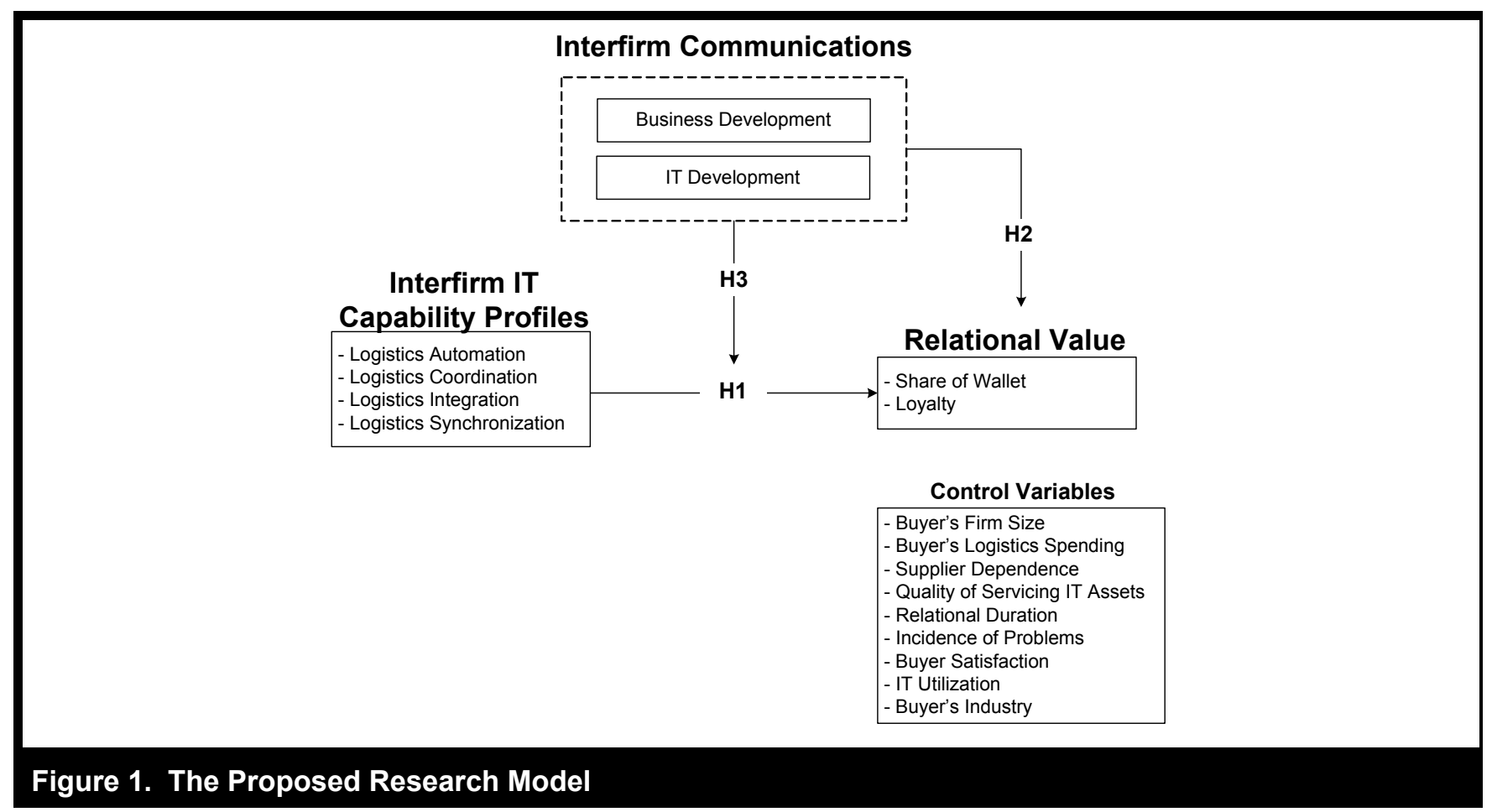

The relational view posits four determinants of relational value: relationship-specific assets, knowledge-sharing routines, complementary resources and capabilities, and effective governance. While relationship-specific assets focus on dedicated investments and structural safeguards to oversee the relationship, IT capabilities and knowledge-sharing routines are IT-intensive variables related to the relationship's business processes. Accordingly, we focus on interfirm IT capability profiles and interfirm communications as interrelated determinants of relational value, which are proposed both independently and in combination to help interfirm relationships cocreate relational value. Figure 1 presents the proposed research model illustrating how interfirm IT capability profiles and interfirm communications for business development and IT development help to separately and jointly cocreate relational value (share of wallet and loyalty) in the logistics industry context.

\section{Relational Value}

While the resource-based view uses the firm as the unit of analysis and focuses on firm-specific resources and capabilities, the relational view uses the interfirm relationship as the unit of analysis and focuses on joint capabilities for collaborative advantage (D'Adderio 2001; Dyer 2000; Dyer and Singh 1998; Jap 2001). Collaborative advantage is essen- tially a joint competitive advantage for both firms in the interfirm relationship that implies the competitive success of the interfirm relationship.

We propose share of wallet and loyalty as the two relevant measures of relational value in this study. Following Cooil et al. (2007, p. 68), share of wallet is defined as "the percentage of money a customer allocates in a category that is assigned to a specific firm."3 Loyalty is defined as "a deeply held commitment to rebuy or re-patronize a preferred product/ service in the future" (Oliver 1980, p. 34).

Share of wallet and loyalty are suitable measures of relational value, as they represent outcomes of interfirm relationships in contrast to measures of quality (e.g., product quality, performance of sales representatives, reliability of hardware and software) or buyer satisfaction (Bowman and Narayandas 2004). Indeed, past studies show that satisfied buyers may not disproportionately allocate resources to a supplier and

\footnotetext{
${ }^{3}$ Share of wallet represents the percentage of money given by the buyer to the supplier, not the absolute amount of money spent by the buyer. The lattersupplier dependence - captures the absolute revenue earned by the supplier from the buyer (normalized by total supplier revenues) and is used as a control variable. Share of wallet is also distinct from transaction volume, which is the volume of packages shipped by the buyer using the supplier, which is also used as a control variable.
} 
may not assess the relationship as being effective in creating value, thus raising the need to distinguish measures of relational value from the buyer's appraisals of the supplier's elements and overall services (e.g., Bowman and Narayandas 2004; Gomez et al. 2004; Jones and Sasser 1995). In contrast to such appraisals, share of wallet translates into the percentage of a buyer's logistics spending that is outsourced to a supplier, indicating a competitive preference. ${ }^{4}$ Bowman and Narayandas explain that share of wallet is a key success measure of interfirm relationships because buyers not only assess the supplier with respect to quality but also relative to competing suppliers. Share of wallet is also an especially pertinent measure of relational value in the logistics industry for two reasons. First, there is a sizeable number of logistics suppliers, many of which are very large firms (e.g., Airborne, DHL, Federal Express, UPS). In 2008, the gross revenues for the the top 50 global logistics service providers was at least $\$ 1$ billion and as much as $\$ 37$ billion (Armstrong \& Associates 2009). Second, buyers exhibit significant variation in the sourcing of their logistics services to suppliers with top buyers using as many as 43 different logistics service providers (Coyle et al. 2009). Accordingly, a higher share of wallet implies that a buyer opts for fewer providers. The example of HP and UPS underscores the appropriateness of share of wallet as a measure of relational value by reflecting how two firms created a mutually beneficial relationship in their logistics processes, which has translated into a larger share of wallet for UPS in terms of HP's logistics budget. It also enhanced HP's ability to deploy the IT functionalities provided by UPS to manage the flow of physical goods, information, and finances across locations in its global supply chain, eventually resulting in an increased (relational) value for both firms.

The academic literature has also viewed share of wallet as a suitable success measure of interfirm relationships. Garland (2004) examines the role of share of wallet in predicting buyer profitability, showing that it has the most impact on buyer contribution to profits, while Reinartz et al. (2005) found share of wallet to positively affect buyer profitability. Thus, share of wallet is an important measure of relationship success that affects other financial measures of success (e.g., Cooil et al. 2007), such as revenues and profits (Anderson and Mittal 2000; Bowman and Narayandas 2004; Keiningham et al. 2005). We also consider loyalty as a suitable measure of relational value, as it reflects the buyer's commitment to a mutually beneficial relationship that results in other measures

\footnotetext{
${ }^{4}$ However, when a buyer allocates a small share of wallet to a certain supplier, it is possible that the buyer allocates the remaining greater share of wallet to a single competitive supplier and does not necessarily use a large number of suppliers.
}

of relationship success (e.g., Bowman and Narayandas 2004; Cunningham 1956; Palmatier et al. 2008; Wind 1970). In sum, building on the literature on interfirm relationships, we propose share of wallet and loyalty as two suitable outcome measures to capture the cocreation of interfirm relational value.

\section{Profiles of Interfirm IT Capabilities for Relational Value}

\section{Development of Interfirm IT Capability Profiles from IT Functionalities}

Capabilities are developed through the combination of resources, and they denote high-performing business processes that are repeated over time to execute business tasks (Amit and Schoemaker 1993; Bingham et al. 2007; Grant 1996). IT capabilities have been defined by Bharadwaj (2000, p. 160) as "the ability to mobilize and deploy IT-based resources in combination or copresent with other resources and capabilities." This definition is rooted in the resourcebased view (Mata et al. 1995), which notes that IT-based resources, such as IT functionalities, when used in combination with other resources (e.g., physical goods, information, and finances in the context of the logistics industry), build IT capabilities that are valuable, rare, non-imitable, and nonsubstitutable and are heterogeneously distributed across firms (Barney 1991). The IT embeddedness view also sees IT functionalities as being embedded with other resources to develop IT capabilities (Kohli and Grover 2008). Thus, integrating the literature, ${ }^{5}$ while IT functionalities may be mobile and imitable (generic) IT resources, IT capabilities rely on the implementation and use of IT functionalities in combination with other resources (e.g., information) that are difficult to imitate or substitute, thus making them a potential source of competitive advantage (e.g., Banker et al. 2006; Bharadwaj 2000; Pavlou and El Sawy 2006; Zhu and Kraemer 2002).

IT capabilities draw upon, but differ from, IT functionalities in that IT functionalities refer to IT assets (or IT resources), while IT capabilities refer to the ability to implement and use IT assets (IT functionalities) in combination with other

\footnotetext{
${ }^{5}$ For a review of the literature on how IT resources are used together with other resources to build IT capabilities, see Banker et al. (2006) in manufacturing plants, Bharadwaj (2000) in high-technology firms, Pavlou and El Sawy (2006) in product development, Ray et al. (2005) in the customer service process, Tanriverdi (2006) in multibusiness firms, Tanriverdi (2005) and Tanriverdi and Venkatraman (2005) in knowledge management, Rai, Im, and Hornyak (2009) in supply chain coordination, and Mishra et al. (2007) and Rai, Brown, and Tang (2009) in procurement.
} 
resources to execute business processes. Simply put, IT functionality is the tool that was designed to help with a business process, while IT capability refers to the implementation and use of IT functionalities with other resources to execute business processes. Our theorization first draws upon the study by Bharadwaj (2000), which distinguishes between the existence of IT-based resources and their mobilization and deployment with other resources to develop IT capabilities. Second, our theorization is informed by Banker et al.'s (2006) notion that IT functionalities are the "building blocks" (p. 318) that need to be implemented in practice to represent IT capabilities. ${ }^{6}$ Third, our theorization is informed by Devaraj and Kohli (2003) who show that the actual use of IT is necessary to create payoffs from IT investments. Integrating these perspectives, IT functionalities must be implemented (corresponding to Banker et al.'s and Bharadwaj's notions of mobilization and deployment) and actually used (corresponding to Devaraj and Kohli's notion of utilization) to form IT capabilities. Extended to interfirm relationships, IT capabilities are formed by implementing and using IT functionalities along with other resources to execute interfirm processes. The differences in the IT functionalities that are implemented and used in interfirm relationships in combination with complementary resources give rise to potentially different IT capabilities across interfirm relationships to execute interfirm business processes.

Based on the logic that IT functionalities must be implemented and used to build IT capabilities, the higher the number of more advanced IT functionalities implemented and used, the more sophisticated the resulting profile of IT capability should be. More sophisticated IT capability profiles are likely to be more valuable and rare, and more difficult for competitors to imitate or substitute. This is because a higher number of progressively more advanced IT functionalities, when implemented and used in interfirm relationships, can render the basis to facilitate the resource flows associated with the complex interdependencies of interfirm processes. We propose the term interfirm IT capability profiles as a grouping of interfirm relationships that implements and uses a set of IT functionalities to execute business processes. Implementing and using a set of more advanced IT functionalities is likely to result in a more sophisticated IT capability profile for the grouping of interfirm relationships, enabling them to execute their interfirm business processes more effectively. We define interfirm IT capability profiles

\footnotetext{
${ }^{6}$ Banker et al. measured just-in-time (manufacturing) capabilities as the extent of implementation of 14 types of manufacturing practices and plant information systems as the extent of implementation of 11 types of IS applications commonly used in the industry.
}

as the ability of a grouping of interfirm relationships to execute interfirm business processes based on a set of IT functionalities that is implemented and used in combination with other business resources.

In the logistics industry, a higher number of advanced IT functionalities that are specific to the logistics process can be implemented and used to manage interdependencies in interfirm logistics activities, thus leading to more sophisticated interfirm IT capability profiles that have the potential to create higher relational value (as we formally hypothesize below).

\section{Proposed Set of IT Functionalities in the Logistics Industry}

Four IT functionalities specific to the logistics industry are proposed to help form sophisticated interfirm IT capability profiles. The logistics process can be described as the flow of physical goods, information, and finances across locations (Rai et al. 2006). As such, resources to be managed in the logistics process are not only the shipping/receiving locations but also the physical goods, information, and finances that flow across these locations. Shipping of physical goods is the basic logistics activity and increases in complexity with the number of shipping/receiving locations (Simchi-Levi et al. 2008). The logistics process also involves the activity of sharing of information about logistics events and the activity of exchanging finances based on these events. The complex interdependencies of interfirm business processes increase as the activities are expanded from (1) automating the basic shipping of physical goods from a single location to (2) coordinating shipping of goods from multiple locations to (3) sharing information about logistics events across the supply chain to (4) synchronizing the settlement of financial exchanges based on logistics events. Interfirm logistics relationships that were able to effectively manage these four key logistics activities were shown to create value in terms of cost efficiencies and market responsiveness (Rai et al. 2006; Simchi-Levi et al. 2008).

Given the value that can be created by managing the four key activities of the logistics process pertaining to the flow of physical goods, information, and finances across locations, logistics suppliers (e.g., UPS, Federal Express, DHL), and IT vendors (e.g., SAP, Oracle) have built IT functionalities to manage the flow of resources in the interfirm logistics processes. We identify four progressively more advanced sets of IT functionalities (Table 1) that, when implemented and used in interfirm logistics relationships to execute logistics processes, can form IT capability profiles of increased sophistication. 


\begin{tabular}{|c|c|}
\hline IT Functionality & Description of IT Functionality \\
\hline $\begin{array}{l}\text { Single-location } \\
\text { shipping } \\
\text { IT functionality }\end{array}$ & $\begin{array}{l}\text { - Captures shipment characteristics and transmits shipping requirements to the supplier } \\
\text { - Generates identification information for packages and shipping labels that can be read by supplier's } \\
\text { scanners } \\
\text { - Bundles basic web-based coarse tracking of shipments across two locations } \\
\text { - Bundles basic billing that logs invoicing and payment at a single shipping location }\end{array}$ \\
\hline $\begin{array}{l}\text { Multilocation } \\
\text { shipping } \\
\text { IT functionality }\end{array}$ & $\begin{array}{l}\text { - Achieves interoperability across systems at multiple shipping/receiving locations } \\
\text { - Supports multiple standards for data sharing on shipping requirements across multiple locations } \\
\text { (e.g., plants and warehouses) }\end{array}$ \\
\hline $\begin{array}{l}\text { Supply chain } \\
\text { visibility } \\
\text { IT functionality }\end{array}$ & $\begin{array}{l}\text { - Captures granular, detailed information on events and the status of stocks and flows of shipments in } \\
\text { the interfirm logistics process } \\
\text { - Integrates information on buyer's inventory positions and flow of goods across multiple locations } \\
\text { (e.g., production, distribution) } \\
\text { - Cascades alerts on exceptions that have occurred or are expected to occur (e.g., shipment delay) }\end{array}$ \\
\hline $\begin{array}{l}\text { Financial } \\
\text { settlement } \\
\text { IT functionality }\end{array}$ & $\begin{array}{l}\text { - Stores business rules on logistics events that drive financial settlement among parties in the supply } \\
\text { chain } \\
\text { - Settles invoicing and payments among partners in the supply chain based on logistics events and } \\
\text { pre-negotiated business rules }\end{array}$ \\
\hline
\end{tabular}

Single-location shipping IT functionality captures the shipping characteristics of physical goods (e.g., weight, dimensions), handling instructions (e.g., temperature control, hazardous materials), and transportation mode (e.g., ground, air, overnight) and transmits these shipping characteristics from the buyer's location to the supplier. It also generates and prints shipping labels with identification information that maps to the shipping characteristics. This shipping label enables tracking the stocks and flows of physical goods throughout the supply chain. The single-location shipping IT functionality also includes basic package tracking (which is now a standardized service that accompanies the shipping of physical goods and is even available online to consumers). The shipping IT functionality also provides basic billing such that bills are generated periodically based on the shipping transactions logged at the shipping location. Similar to basic tracking, this is also a standardized service that accompanies the creation of a shipping account with the supplier at the buyer's shipping location.

Multilocation shipping IT functionality focuses on optimizing the scheduling and routing of shipment pickups across the buyer's multiple shipping locations (e.g., warehouses and plants) and channels (online and offline). The functionality also coordinates picking, packing, storing, transporting, and delivering of physical goods shipped from multiple locations. This IT functionality enables the interoperability of heterogeneous IT systems, and it supports multiple standards (e.g.,
EDI, XML) for sharing data about shipment requirements across shipping locations in the buyer's supply chain.

Supply chain visibility IT functionality provides a unified, detailed view of inventory positions and in-transit shipments in the interfirm logistics process and cascades alerts on critical events. While basic tracking provides coarse information on the movement of a shipment from one location to another, the supply chain visibility IT functionality generates granular information on the stocks and flows of physical goods across locations and integrates information on logistics events across locations to develop a unified view. For example, UPS has designed a supply chain visibility IT functionality for global manufacturing firms, such as HP. This IT functionality traces the stocks and flows of a firm's products from production planning to production and shipment by contract manufacturers to storage and movement by freight-forwarders and ocean carriers to inspection and clearance by customs authorities to the final stages of inland shipment by warehouse facilities and ultimately to their final destination.

Financial settlement IT functionality stores business rules on events that trigger financial exchanges among buyers and suppliers in the interfirm logistics process and on electronic funds transfer into the designated bank accounts of these firms. It also executes financial transactions when predefined events occur in the logistics process. For example, HP's elec- 
Table 2. Proposed Interfirm IT Capability Profiles in the Logistics Industry

\begin{tabular}{|l|l|}
\hline \multicolumn{1}{|c|}{ IT Capability Profiles } & \multicolumn{1}{c|}{ Description of Interfirm IT Capability Profiles } \\
\hline $\begin{array}{l}\text { Profile A: } \\
\text { Logistics Automation }\end{array}$ & $\begin{array}{l}\text { The ability to automate shipping by initiating, scheduling, and executing the shipping of } \\
\text { physical goods at the buyer's shipping location, automating the coarse tracking of shipments, } \\
\text { and facilitating billing using the transaction history of shipping activities at a location. }\end{array}$ \\
\hline $\begin{array}{l}\text { Profile B: } \\
\text { Logistics Coordination }\end{array}$ & $\begin{array}{l}\text { The ability to coordinate the shipping of physical goods across the buyer's multiple shipping } \\
\text { locations by optimizing the routing and scheduling of shipments, merging related shipments } \\
\text { across locations, and consolidating the transaction history of shipping activities across } \\
\text { locations for billing. }\end{array}$ \\
\hline $\begin{array}{l}\text { Profile C: } \\
\text { Logistics Integration }\end{array}$ & $\begin{array}{l}\text { The ability to integrate information, including plans and exceptions, on events related to the } \\
\text { stocks and flows of physical goods across locations in the buyer's supply chain. }\end{array}$ \\
\hline $\begin{array}{l}\text { Profile D: } \\
\text { Logistics Synchronization }\end{array}$ & $\begin{array}{l}\text { The ability to synchronize the flow of physical goods, information, and finances across parties } \\
\text { in the buyer's supply chain by changing the ownership of physical goods and settling financial } \\
\text { transactions based on logistics events. }\end{array}$ \\
\hline
\end{tabular}

tronic payments to customs agencies are triggered when the physical goods clear customs inspection. Similarly, HP applies business rules negotiated with its suppliers on logistics events that transfer inventory ownership and authorizes electronic funds transfer from one party to another in its supply chain.

\section{Proposed Interfirm IT Capability Profiles in the Logistics Industry}

We theorize that sets of progressively more advanced IT functionalities, when implemented and used in combination with other resources (i.e., physical goods, information, finances, locations) in logistics processes, can form distinct interfirm IT capability profiles of increased sophistication to help execute the key activities in the interfirm logistics process - namely, (1) automating the basic shipping of physical goods from a single location, (2) coordinating shipping of goods from multiple locations, (3) sharing information about logistics events across the supply chain, (4) synchronizing the settlement of financial exchanges based on these logistics events (as summarized in Table 2).

Logistics Automation IT Capability Profile (A): The implementation and use of the single-location shipping IT functionality helps form the logistics automation IT capability profile, which automates the execution of shipping transactions (flow of physical goods) from the buyer's shipping location to the final destination. This IT capability profile represents the ability of interfirm logistics relationships to automate package labeling, schedule pickup/delivery times for shipments, and specify special processing requirements. As such, it reflects the ability to remove errors from shipping activities that entail the codification of a significant volume of data for each shipment. It also represents the ability to offer coarse web-based tracking of the movement of physical goods from the supplier picking up a good from the buyer's shipping location to its final destination. Since the information provided by the IT functionality is highly coarse, the IT capability profile allows basic tracking information to be shared by the supplier to the buyer only about the movement of physical goods through predefined scanning locations, such as pickup, trucks loading, and final receipt. The basic billing support provided by the IT functionality enables periodic invoicing by the supplier and scheduled automatic payments by the buyer. Thus, the implementation and use of the single shipping location IT functionality forms the interfirm logistics automation IT capability profile that reflects the ability to automate logistics in terms of the basic flow of physical goods, basic shipment tracking, and basic billing and payment.

Logistics Coordination IT Capability Profile (B): The implementation and use of the multilocation shipping IT functionality augments the single-location shipping functionality to form an IT capability profile that coordinates shipping of physical goods and consolidates payments across multiple locations. The logistics coordination IT capability profile represents an integrated view of the buyer's shipping requirements across multiple locations and enables better coordination of shipments from multiple locations and optimal routing of shipments across locations. As such, the implementation and use of IT functionalities to automate shipping transactions at one location and to coordinate them across locations represents the logistics coordination IT capability profile, which provides interfirm relationships the ability to execute interdependent shipping transactions and consolidate billing across multiple locations. 
Logistics Integration IT Capability Profile (C): The implementation and use of the supply chain visibility IT functionality augments the single- and multiple-location shipping IT functionalities to form the logistics integration IT capability profile that helps obtain fine-grained information on the flows of physical goods across locations (Im and Rai 2008; Klein and Rai 2009). This IT capability profile enables the integration of information on the status of physical goods (instock or in-transit) and exceptions/alerts on the flows of physical goods based on existing rules (Bala and Venkatesh 2007). Given the complex information in interfirm logistics processes, the logistics integration IT capability profile enables synergies across activities, such as inventory management, production, and distribution (Bharadwaj et al. 2007). In sum, the logistics integration IT capability profile reflects the ability of interfirm logistics relationships to automate the shipping of physical goods at each location, coordinate shipping and billing across multiple locations, and provide visibility of the flows of goods across multiple locations in the supply chain by sharing granular information on logistics events.

Logistics Synchronization IT Capability Profile (D): The implementation and use of the settlement IT functionality augments the three aforementioned IT functionalities (singlelocation and multiple-location shipping IT functionalities and supply chain visibility IT functionality) to form the logistics synchronization IT capability profile. This profile enables event-based executions of financial transactions to transfer ownership of physical goods and finances across parties in the supply chain. Financial transactions are based on logistics events and business rules for financial flows, such as invoicing on shipment/delivery and automating payments when an electronic signature is recorded. Since these financial transactions are triggered by real-time events, they can be used to transfer inventory ownership in a timely manner, reduce inventory levels, accelerate payments for fulfilled orders, reduce days of sales outstanding, and reduce cash conversion cycles. As such, this IT capability profile reflects the ability to synchronize the logistics process by facilitating shipping transactions at each location, coordinate shipping transactions across locations, offer granular information on logistics events on the stocks and flows of physical goods, and execute financial flows among parties in the supply chain based on event-based business rules.

In sum, each succeding IT capability profile (Table 2) relies on the implementation and use of progressively more advanced IT functionalities, ${ }^{7}$ forming a more sophisticated IT

\footnotetext{
${ }^{7}$ While these four IT capability profiles are hierarchically categorized as less to more sophisticated, it is not necessary to sequentially progress through these IT capability profiles. For example, a relationship can decide on
}

capability profile to execute logistics processes by facilitating the interdependencies in the flows of physical goods, information, and finances across locations. The more sophisticated IT capability profiles are proposed to be rarer and more valuable than the less sophisticated ones by better facilitating interfirm logistics processes, thereby more difficult to imitate or substitute. Therefore, more sophisticated IT capability profiles are proposed to help cocreate higher relational value, as justified in more detail below.

\section{Interfirm IT Capability Profiles and Relational Value}

We propose that more sophisticated IT capability profiles will be associated with higher relational value by allowing the interfirm relationship to better manage the complex interdependencies of the flows of physical goods, information, and finances across locations. First, the logistics coordination IT capability profile that enables coordination across many shipping locations is likely to create higher relational value than the shipping automation IT capability profile that only automates transactions at a single location, thus yielding productivity across multiple locations. This is because coordinating shipping across multiple locations can facilitate the flows of physical goods (e.g., scheduling and routing of multipart shipments where parts ship from different locations and merge together in transit) and the streamlined exchange of finances in the buyer's supply chain. Moreover, consolidated billing across multiple shipping locations facilitates the integrated financial management of the relationship in contrast to siloed management of accounts fragmented across shipping locations, thus resulting in higher relational value for the interfirm relationship.

Second, the logistics integration IT capability profile that enables visibility across the supply chain, is likely to create higher relational value than the logistics coordination IT capability profile that only automates and coordinates across shipping locations. It can faciliate managing the interdependencies in logistics activities by integrating granular information across locations on logistics events related to the flows of physical goods, as well as on plans and exceptions related to physical flows (e.g., causes of inefficiencies in physical flows, time value of in-transit inventory given transportation mode choices for physical flows, impact of posi-

Profile D right away. Similarly, it is possible that relationships move from Profile A to Profile D without going through any intermediate steps. Simply put, each interfirm relationship chooses which set of IT functionalities it needs to execute its logistics processes, and the IT functionalities are implemented and used to form an interfirm IT capability profile to execute logistics processes. 
tioning distribution hubs and routing shipments on order fulfillment service levels and revenue losses). Such integrated visibility on logistics events not only enables the global optimization of logistics activities, but it also facilitates the management of interdependencies of the logistics process together with other core processes (e.g., production and distribution).

Third, the logistics synchronization IT capability profilewhich automates and coordinates the shipping of physical goods across locations, offers visibility into the buyer's supply chain by integrating information flows, and settles financial exchanges in the interfirm logistics process-is proposed to create the highest relational value compared to the other profiles. This is because an IT capability that seamlessly synchronizes the flow of physical goods, information, and finances across multiple locations in the supply chain by transferring the ownership of physical goods and finances based on information on logistics events helps the interfirm relationship expand its ability to manage its interdependencies and increase its potential for relational value. By expanding the sophistication of the interfirm IT capability in this manner, the firm's inventory turns, and cash-to-cash conversion cycles can be improved, thus enhancing relational value from interfirm business processes (Simchi-Levi et al. 2008). Bestpractice firms (e.g., Apple, Disney, Research in Motion, Amazon, Wal-Mart, Cisco Systems, Sport Obermeyer) have established such sophisticated IT capabilities to manage the interdependencies in the flows of physical goods, information, and finances when executing their interfirm business processes (O'Marah and Hofman 2010). Therefore, an IT capability profile that helps manage logistics processes by automating and coordinating shipping across many locations, integrating information flows, and seamlessly settling finances helps interfirm relationships increase productivity at each location, reduce coordination costs across locations, optimize inventory stocks and flows across locations in the buyer's supply chain, and synchronize the exchange of physical goods and finances.

In sum, these four distinct IT capability profiles are progressively more sophisticated in their ability to manage the interdependencies of interfirm logistics processes by relying on increasingly more advanced sets of IT functionalities. Accordingly, each more progressively sophisticated IT capability profile is proposed to have an increasingly higher effect on relational value. We thus hypothesize:

H1: More sophisticated interfirm IT capability profiles are associated with higher relational value such that (a) the logistics coordination profile is associated with a higher relational value than the logistics automation profile, (b) the logistics integration profile is associated with a higher relational value than the logistics coordination profile, and (c) the logistics synchronization profile is associated with a higher relational value than the logistics integration profile.

\section{Interfirm Communications for Relational Value}

We define interfirm communications as the exchange of knowledge, ideas, and opinions driven by goals among senior executives in the interfirm relationship (Kellermann 1992; Rapert et al. 2002). In contrast to standardized and operational information sharing supported by interfirm IT capabilities (to support routine logistics activities) or through communications with operational support personnel (to handle problems and correct errors), interfirm communications focus on both generating a better understanding of each firm's plans, objectives, resources, and capabilities and on building a consensus on the opportunities and challenges facing the relationship (Klein and Rai 2009; Rapert et al. 2002). Interfirm communications were shown to enhance mutual understanding and establish the context for partnering firms to meaningfully discuss ways to collaborate and jointly generate beneficial outcomes (Chan 2002). Benefits that accrue from communications have been examined within a firm (e.g., between the CIO and CEO) (Chan 2002), between firms (e.g., strategic alliances, supply chain) (Klein and Rai 2009), and even between nations (e.g., diplomacy by U.S. presidents) (Paul 2009).

In general, interfirm communications have been characterized by their frequency (i.e., quantity), directionality (unidirectional versus bidirectional), formality (structured and detailed versus unstructured and general), and coerciveness (noncoercive versus coercive) (Mohr et al. 1996; Mohr and Nevin 1990). Historically, Chase (1978) introduced the term customer contact to describe the quality of interfirm interactions. In buyer-supplier relationships, contact stream was later proposed in the marketing (e.g., Berry 1980; Lovelock and Wirtz 1984), management (e.g., Bowen 1986; Chase and Tansik 1983), and operations research (Chase 1981) literatures as a derivative concept of interfirm communications. Contact stream includes instances when firms interact, such as being physically present at each other's facilities, or collaborating in product development (e.g., Mills 1986). Contact stream represents the coupling, interdependence, and information richness in a relationship (Kellogg and Chase 2005), where coupling captures the strength of links in the relationship (Weick 1976), interdependence captures the extent to which each partner's actions is contingent on the other partner 
(Victor and Blackburn 1987), and information richness reflects personalized, as opposed to mechanistic, forms of interaction (Child 1987). These dimensions were operationalized into a measure of contact stream with three facets: communication time, level of intimacy, and information richness (Kellogg and Chase 2005). All three are likely to be high when senior executives interact directly. Our focus is on the contact stream among senior executives who engage in interfirm communications and would pertain to instances when senior executives interact directly to exchange information, ideas, and opinions on the interfirm relationship. The benefits of a frequent, rich, and intimate contact stream among buyers and suppliers have been widely identified in the literature (e.g., Bowen 1986; Bowen et al. 1989). Bearden et al. (1998) linked contact stream to satisfaction, and Venkatesan and Kumar (2004) linked contact stream with transaction volume and lifetime value. ${ }^{8}$ Accordingly, we expect the extent of the contact stream for communications among senior executives between firms in an interfirm relationship to help create relational value, as explained below.

In the logistics industry, interfirm communications typically occur in the form of direct contact among account and IT executives (Earl 2001; Froehle and Roth 2004). These interactions can involve meetings among senior executives to evaluate new opportunities for collaboration and review sessions to assess the supplier's performance against negotiated service level agreements, examine necessary adjustments in the relationship's business plans, and address emergent issues. These interactions rely on tangible managerial resources that are explicitly dedicated to enhancing the interfirm relationship by both partners because direct and frequent communications require investments in time and expertise. Also, to the extent that the direct contact among the senior executives is extensive, they are likely to promote shared understanding and intimacy. Hence, we propose that the frequency of a direct contact stream among senior executives is a reasonable proxy for the time and expertise dedicated by both firms to communications toward business and IT development in the interfirm relationship, thereby creating opportunities for the interfirm relationship to cocreate relational value, as we explain below.

\footnotetext{
${ }^{8}$ Venkatesan and Kumar actually showed an inverted-U relationship between contact stream and positive benefits where too much contact results in dysfunctional communication and worse performance. This is because excessive contact with the customer may be beneficial from a sales and a customer relationship management perspective, but the cost and efficiency by which the contact occurs must also be taken under consideration (Bowen and Jones 1986; Collier 1983).
}

\section{Interfirm Communications for Business Development}

Interfirm communications for business development are oriented toward both leveraging current interdependencies and exploring plausible future interdependencies in interfirm logistics processes (Klein et al. 2007). They entail assessing how to reduce inefficiencies and increase the responsiveness of the interfirm logistics process. They also help identify new opportunities for cocreating value (Rai and Sambamurthy 2006). The supplier's account executives are responsible for communicating with their buyers to understand their evolving logistics requirements, informing the buyers about their current and projected logistics capabilities, and evaluating opportunities for relational value cocreation. ${ }^{9}$ Hence, the time, richness, and intimacy of the contact stream between account executives when engaging in interfirm communications can facilitate business development in the relationship by fostering partner-specific learning (Paulraj et al. 2008), and it can provide contextual understanding for the partners to collaborate for relational value cocreation. Therefore, we hypothesize:

\section{H2a: Higher relational value is associated with more frequent interfirm communications pertaining to business development.}

\section{Interfirm Communications for IT Development}

The notion of contact stream in interfirm relationships also extends to technological or IT aspects (Gefen and Ridings 2002; Henderson and Clark 1990; Holweg and Pil 2008). Direct communication among the partners' IT executives can help them develop a mutual understanding of how IT can better support the interfirm logistics process. It also enables executives to strategize about joint IT initiatives to overcome inefficiencies in the logistics process or create opportunities for innovation with the aid of IT. Given the important role of IT in interfirm relationships, particularly in the logistics

\footnotetext{
${ }^{9}$ Examples of communications include determining how product launches can be jointly orchestrated when product life cycles are short and product demand is uncertain; evaluating merge-in-transit opportunities for multipart shipments coming from different locations; analyzing, repositioning, or consolidating stocking locations across the buyer's supply chain based on the supplier's logistics capabilities in different regions; determining the velocity of the flows of physical goods based on the time value of goods and the multiple modes of transportation that can be deployed by the supplier; examining the routing shipments of goods through various countries based on tax or tariff implications; and exploring ways that the supplier can capture and share information on specific logistics events (e.g., proof of delivery, customs clearance, exceptions) that can trigger financial flows.
} 
industry, the supplier's IT executives are responsible for communicating with buyers to better understand their IT needs, informing them about their evolving IT functionalities, learning about the buyer's new IT systems, and discussing with them how IT functionalities can be implemented and used in the logistics process to help create relational value. ${ }^{10}$ Therefore, we hypothesize:

\section{H2b: Higher relational value is associated with more frequent interfirm communications pertaining to IT development.}

\section{Interaction Effects among the Direct Determinants of Relational Value}

We also examine how the proposed interfirm IT capability profiles interact with interfirm communications for business development and IT development to further cocreate relational value. Extending the relational view that only theorized direct determinants of relational value, we propose that interfirm IT capability profiles and interfirm communications have an interaction effect by complementing each other to jointly help cocreate relational value in interfirm relationships.

We theorize that interfirm communications reinforce the ability of interfirm IT capabilities to create relational value since interfirm communications foster interfirm learning (Powell et al. 1996). As interfirm logistics processes are complex, situational, and ongoing, it is useful for partnering firms to engage in frequent communications to learn how their interfirm logistics processes can be enhanced with IT capabilities. Besides, interfirm logistics processes are not static; buyers and suppliers adjust their actions based on changes to technologies, roles, and responsibilities. Moreover, interfirm communications help promote mutual understanding about the relationship's objectives, assumptions, and roles. Interfirm communications also build cooperation and trust and reduce conflict (Anderson and Weitz 1992; Anderson and Narus 1990), thus promoting mutual adjustment and helping enhance the effect of interfirm IT capability profiles for cocreating relational value.

\footnotetext{
${ }^{10}$ Such communications pertain to how automation of the logistics process can be used to preempt shipping errors; what data, application, and process standards should be used to enhance the interfirm logistics process; how IT can grant supply chain visibility (e.g., RFID tracking) and discover patterns of logistics events and outcomes (e.g., data mining); how IT can increase the adaptation of the interfirm logistics process to unanticipated events (e.g., cascading events and exceptions to supply chain partners); and what IT applications need to be developed to integrate the buyer's IT systems more effectively with the supplier's IT systems.
}

As open and frequent communication helps facilitate the development of contextual knowledge (Kotabe et al. 2003; Takeishi 2001), frequent interfirm communications help relationships develop knowledge on how to integrate IT functionalities with the buyer's and supplier's respective IT systems and how to better embed IT functionalities in interfirm logistics processes. HP and UPS, for example, overcome IT integration challenges in their interfirm logistics process by regularly informing each other about their plans, such as implementing new business process standards (business knowledge) or new ERP systems (IT knowledge). These firms discover opportunities to use new IT functionalities for executing logistics processes by sharing business plans on product markets (e.g., expanding presence in an existing market or launching a new product). Such frequent interfirm communications have enabled HP and UPS to not only ensure the continuity of their logistics process but also to pursue new opportunities for value cocreation. Also, when HP and Compaq were in the merger process, HP's executives regularly communicated about HP's plans for business and IT integration with Compaq so that UPS and the post-merger HP/Compaq were ready to integrate their IT systems with those of UPS. In sum, frequent interfirm communications are useful for coordinating business and IT development to ensure that IT functionalities are implemented and used to execute the interfirm logistics processes.

Interfirm communications for business development and IT development are also a rich forum to negotiate improvements in logistics processes that interfirm IT capability profiles can support. Such communications enhance the supplier's knowledge of the buyer's needs, thus raising the ability to enhance business processes (Joshi 2009). For example, business and IT knowledge helps orchestrate logistics activities across multiple locations with the logistics coordination IT capability profile. Moreover, business and IT interfirm communications can reveal opportunities to better integrate shipping and receiving activities with the aid of the logistics integration IT capability profile. Frequent business and IT interfirm communications can also identify opportunities for further improving financial exchanges based on logistics events, which can be realized with the logistics synchronization IT capability profile. In sum, interfirm communications for business development and IT development can complement the ability of the proposed IT capability profiles to cocreate relational value. Dyer and Singh (1998) also note that infrequent interactions limit partners' ability to identify opportunities for relational value. Furthermore, the value created by the proposed IT capability profiles is contingent on many factors, and the mismanagement of these factors in the absence of frequent and rich interfirm communications can inhibit relational value creation (Sabherwal and Chan 2001; Sabherwal and Kirs 1994). Accordingly, a more frequent contact stream for 
interfirm communications among executives on business and IT development is proposed to boost the proposed effect of IT capability profiles on relational value. Thus, we propose the following hypotheses:

\section{H3: The positive association between more sophisticated interfirm IT capability profiles and relational value is positively moderated by more frequent interfirm communications pertaining to (a) business develop- ment and (b) IT development.}

\section{Control Variables}

There are many determinants of relational value that we include as control variables. We include buyer's satisfaction with the supplier, which has been linked to share of wallet (e.g., Baumann et al. 2005; Bowman and Narayandas 2004; Cooil et al. 2007; Magi 2003; Perkins-Munn et al. 2005; Rust and Zaborik 1993) and loyalty (e.g., Callarisa Fiol et al. 2009; Loveman 1998). Relationship duration captures the effects of relationship longevity on share of wallet (Klein and Rai 2009) and loyalty (Gulati 1995). We also control for the buyer's firm size because large firms are less likely to raise their share of wallet, partly due to their complex processes and the need to integrate their processes. Larger firms also tend to place less emphasis on exploiting their partner's IT capabilities because of the potential heterogeneity of their resources (e.g., IT systems and applications, process standards) and challenges in integrating these resources with external partners (Doz 1987). We also control for the supplier dependence on the buyer - namely, the extent of revenue earned by the supplier from the buyer-which increases the supplier's dependence on the buyer and leads the supplier to invest in the relationship (Dyer and Singh 1998). We also include transaction volume to capture the level of activity in the interfirm logistics relationship (number of shipments per week), a measure expected to relate to revenues that the supplier earns from a buyer. We also include the quality of servicing IT assets in the interfirm relationship because the quality of the vendor's IT application and hardware maintenance is important to ensure that IT systems operate reliably in interfirm relationships. Also, we control for the incidence of problems in the interfirm logistics process experienced by the buyer to account for any influence of such experience on relational value. We also control for the IT utilization in an interfirm relationship, as the level of use of the set of implemented IT functionalities to execute the interfirm business process can affect performance outcomes (Kohli and Devaraj 2003). Finally, we control for the buyer's industry since industries may differ in their specialized logistics needs, which could lead buyers to allocate their logistics spending differently across logistics suppliers.

\section{Research Methodology}

\section{Sample and Data Collection}

Following the relational view, our unit of analysis is the interfirm buyer/supplier relationship. Our sample consists of active relationships between a major logistics supplier and its buyers in the United States. The supplier is a Fortune 100 firm and one of the largest logistics suppliers in the world. As the logistics industry has evolved in the last two decades from a primary focus on the transportation of physical goods between two locations to a focus on the total management of the flows of physical goods, information, and finances across many locations in the entire supply chain, the focal logistics supplier has invested aggressively in developing IT functionalities to enhance its logistics services. However, the set of IT functionalities that is implemented and used across buyers varies significantly.

To govern buyer/supplier relationships, standardized contracts are used that specify service level agreements in much detail (e.g., delivery times, quality of shipments, claims). The logistics supplier also dedicates account executives to communicate with buyers on their evolving logistics requirements and the supplier's abilities to service these requirements. Moreover, the supplier assigns IT executives to communicate with the buyer on how IT functionalities can be implemented and used to support interdependencies in the interfirm logistics process. These communications focus on IT developments and process standards, changes in IT applications and IT infrastructure, and uses of IT functionalities. As such, in the context of our empirical study, the account executives and IT executives have strategic responsibilities for the development of the relationship. However, they are not in charge of routine problem resolution, and the primary roles of account executives and IT executives are more strategic in nature and are not focused on handling routine problems (e.g., billing errors, damage claims, lost shipments, system failures). To handle routine problems, the supplier has developed call centers, IT help desks, and claims-processing centers. While there is a high level of standardization in the formal contract that governs the interfirm relationship, the communications among the supplier's account and IT executives with each buyer vary significantly.

We obtained our data by combining four archival sources provided by the focal logistics supplier (Table 3). Appendix A offers details on the measures. The supplier used a third-party market research firm to collect data between late 2004 and early 2006 from a buyer's key decision maker (KDM). The supplier targeted KDMs at a random sample of about 1 percent of its buyers (approximately 3,000 buyers) across indus- 


\begin{tabular}{|c|c|c|c|}
\hline \multirow[b]{2}{*}{ Data Source } & \multicolumn{2}{|l|}{ Variables } & \multirow[b]{2}{*}{ Measure } \\
\hline & Name & Type & \\
\hline \multirow{7}{*}{ KDM archives } & Share of wallet & DV & $\begin{array}{l}\text { Proportion of logistics budget allocated in the current } \\
\text { year by the buyer to the supplier }\end{array}$ \\
\hline & Loyalty & DV & $\begin{array}{l}\text { Mean of three items dealing with the buyer's loyalty to } \\
\text { the supplier }\end{array}$ \\
\hline & Buyer satisfaction with supplier & Control & $\begin{array}{l}\text { Mean of three items dealing with the buyer's overall } \\
\text { satisfaction with the supplier's services }\end{array}$ \\
\hline & Buyer size & Control & Number of employees \\
\hline & Buyer's total logistics spending & Control & Outsourced logistics spending in current year \\
\hline & Quality of servicing IT assets & Control & $\begin{array}{l}\text { Buyer's perception of the supplier's quality of } \\
\text { servicing its IT assets }\end{array}$ \\
\hline & $\begin{array}{l}\text { Incidences of problems } \\
\text { experienced by the buyer }\end{array}$ & Control & $\begin{array}{l}\text { Incidence of problems that the buyer experienced with } \\
\text { the supplier in the last year }\end{array}$ \\
\hline \multirow{2}{*}{$\begin{array}{l}\text { Technology } \\
\text { archives }\end{array}$} & Interfirm IT capability profile & IV & $\begin{array}{l}\text { Profile of IT capability in the previous year (based on } \\
\text { the set of IT functionalities implemented and used) }\end{array}$ \\
\hline & IT utilization & Control & $\begin{array}{l}\text { Percentage of total shipments in the relationship } \\
\text { processed using the set of implemented IT } \\
\text { functionalities }\end{array}$ \\
\hline \multirow{3}{*}{ CRM archives } & $\begin{array}{l}\text { Interfirm communications for } \\
\text { business development }\end{array}$ & IV & $\begin{array}{l}\text { Total number of visits and phone calls in past year } \\
\text { between the supplier's account executives with the } \\
\text { buyer }\end{array}$ \\
\hline & $\begin{array}{l}\text { Interfirm communications for IT } \\
\text { development }\end{array}$ & IV & $\begin{array}{l}\text { Total number of visits and phone calls in past year } \\
\text { between the supplier's IT executives with the buyer }\end{array}$ \\
\hline & Relationship duration & Control & Time (in years) since the account was created \\
\hline \multirow{2}{*}{$\begin{array}{l}\text { Financial } \\
\text { archives }\end{array}$} & Supplier dependence on buyer & Control & Buyer revenue/total revenue for previous year \\
\hline & Transaction volume & Control & Number of shipments/week \\
\hline
\end{tabular}

tries, relationship duration, and revenues. The random sample was formed by active buyers that were supported by an account executive and had at least one package per week on average or $\$ 10,000$ in annual revenue (to be considered a significant logistics relationship). ${ }^{11}$ The market research firm contacted the KDMs by phone and obtained data on share of wallet, loyalty, buyer satisfaction and perceptions of the supplier's quality of servicing the IT hardware and software, firm size, problem incidences, and total logistics spending. ${ }^{12}$

\footnotetext{
${ }^{11}$ The logistics supplier uses this definition for a significant interfirm relationship. We tested our model by using multiple subsamples that restricted the relationships to be more significant in terms of transaction volume (more than 5,10 , or 20 packages/week). We obtained the same pattern of results across any of these subsamples, thus implying robustness.

${ }^{12}$ The vendor's KDM archives include data for a subsample of buyers on buyer's satisfaction with the supplier's problem resolution, frequency of problems experienced by the buyer, and whether the buyer contacted the
}

Our sample profile is shown in Table 4: 65 percent of the KDMs were senior executives, such as presidents, vice presidents, controllers, or directors; 16 percent were account representatives; and the rest were in other logistics positions. The KDM data were matched with the supplier's technology archives on the set of IT functionalities that had been implemented and used in each interfirm relationship. We integrated customer relationship management (CRM) archival records to obtain data on the number of site visits and phone calls between the supplier's executives with the buyer during the past year. We also obtained archival data on financial transactions

account executive or problem-resolution facilities (operational call center, IT help desk, and claims-processing centers) when they had a problem. We obtained this data to evaluate whether the communications with the account and IT executives pertained to routine problems as opposed to strategic communications. Our results, as reported later in our discussion of robustness tests, indicate that this is not the case. 


\begin{tabular}{|c|c|c|}
\hline Variable & Category & Percentage \\
\hline \multirow{3}{*}{$\begin{array}{l}\text { Role of Key Decision Maker } \\
\text { (KDM) in Buyer Firm }\end{array}$} & Executive (president, vice president, controller, director) & $64.5 \%$ \\
\hline & Account representative & $16.2 \%$ \\
\hline & Logistics operations & $19.3 \%$ \\
\hline \multirow{4}{*}{ Industry (NAICS) } & Sector 31-33 (manufacturing) & $33.0 \%$ \\
\hline & Sector 42-49 (wholesale, retail trade, transportation, etc.) & $35.9 \%$ \\
\hline & Sector 51-56 (information, finance and insurance, etc.) & $11.4 \%$ \\
\hline & Other sectors & $19.7 \%$ \\
\hline \multirow{5}{*}{$\begin{array}{l}\text { Relationship Duration } \\
\text { (years) }\end{array}$} & $<5$ & $14.3 \%$ \\
\hline & $\geq 5$ and $<10$ & $24.3 \%$ \\
\hline & $\geq 10$ and $<15$ & $25.8 \%$ \\
\hline & $\geq 15$ and $<20$ & $25.4 \%$ \\
\hline & $\geq 20$ & $10.2 \%$ \\
\hline \multirow{5}{*}{$\begin{array}{l}\text { Buyer Logistics Spending } \\
\text { (\$1000s) }\end{array}$} & $<20$ & $21.1 \%$ \\
\hline & $\geq 20$ and $<50$ & $23.2 \%$ \\
\hline & $\geq 50$ and $<100$ & $17.6 \%$ \\
\hline & $\geq 100$ and $<200$ & $17.8 \%$ \\
\hline & $\geq 200$ & $20.3 \%$ \\
\hline \multirow{5}{*}{$\begin{array}{l}\text { Transaction Volume } \\
\text { (\# of packages per week) }\end{array}$} & $<20$ & $9.2 \%$ \\
\hline & $\geq 20$ and $<50$ & $20.2 \%$ \\
\hline & $\geq 50$ and $<100$ & $22.4 \%$ \\
\hline & $\geq 100$ and $<200$ & $20.8 \%$ \\
\hline & $\geq 200$ & $27.4 \%$ \\
\hline
\end{tabular}

to capture transaction volume, revenues earned by the supplier from each buyer, and the supplier's dependence on the buyer's revenues during the previous year.

After the complex data integration across four archival sources spanning KDMs, technology archives, CRM activities, and financial transactions (Appendix A), we obtained data from 2,061 active interfirm relationships. Our measures for all independent and control variables were based on data for the year prior to when the data on share of wallet and loyalty were collected, which is consistent with the temporal precedence of the proposed research model (Figure 1).

\section{Measures}

Share of wallet and loyalty are used as proxies of relational value. The KDMs who allocate the logistics budget for the total volume of their firm's shipping needs specified the proportion of the total budget that was allocated to the focal supplier in the past year. This measure is similar to past measures of share of wallet, such as the percentage of money the buyer allocates to a supplier (Cooil et al. 2007). Loyalty was measured using the mean of the KDM's response to three items: buyer's overall loyalty to the supplier, buyer's comfort level with the supplier (buyer does not seriously consider offers from the supplier's competitors), and buyer's likelihood to recommend the supplier to its business associates.

For interfirm IT capability profiles, we first obtained information on the portfolio of IT systems the supplier deployed to help buyers manage their flows of physical goods, information, and finances across locations. We coded the IT functionalities for single-location shipping, multilocation shipping coordination, supply chain visibility, and financial settlement that are implemented in each IT system based on our discussions with the supplier's account and IT executives who were responsible for these systems and also based on archival data on the IT functionalities utilized in each interfirm relationship. 
Table 5. Coding Scheme for the Interfirm IT Capability Profiles

\begin{tabular}{|c|c|c|c|c|}
\hline IT Capability Profile & $\begin{array}{c}\text { Set of IT Functionalities Implemented and Used in } \\
\text { the Interfirm Logistics Processes }\end{array}$ & $\begin{array}{l}\text { Percentage of } \\
\text { Relationships }\end{array}$ & $\begin{array}{c}\text { Mean } \\
\text { Utilization of } \\
\text { Each Set of IT } \\
\text { Functionalities }\end{array}$ & $\begin{array}{l}\text { Mean of } \\
\text { Share of } \\
\text { Wallet }\end{array}$ \\
\hline $\begin{array}{l}\text { Profile A } \\
\text { (Logistics Automation) }\end{array}$ & $\begin{array}{l}\text { The single-location shipping IT functionality is } \\
\text { implemented and used }\end{array}$ & $11.0 \%$ & $75 \%$ & $67 \%$ \\
\hline $\begin{array}{l}\text { Profile B } \\
\text { (Logistics Coordination) }\end{array}$ & $\begin{array}{l}\text { The set of IT functionalities implemented and used is } \\
\text { - Single-location shipping } \\
\text { - Multilocation shipping coordination }\end{array}$ & $74.8 \%$ & $87 \%$ & $76 \%$ \\
\hline $\begin{array}{l}\text { Profile C } \\
\text { (Logistics Integration) }\end{array}$ & $\begin{array}{l}\text { The set of IT functionalities implemented and used is } \\
\text { - Single-location shipping } \\
\text { - Multilocation shipping coordination } \\
\text { - Supply chain visibility }\end{array}$ & $12.5 \%$ & $78 \%$ & $80 \%$ \\
\hline $\begin{array}{l}\text { Profile D } \\
\text { (Logistics Synchronization) }\end{array}$ & $\begin{array}{l}\text { The set of IT functionalities implemented and used is } \\
\text { - Single-location shipping } \\
\text { - Multilocation coordination } \\
\text { - Supply chain visibility } \\
\text { - Financial settlement }\end{array}$ & $1.6 \%$ & $93 \%$ & $82 \%$ \\
\hline
\end{tabular}

We validated the coding through in-person and phone discussions with both account and IT executives and lead developers at the supplier side in addition to discussions with the buyer's account executives. The coding scheme was finalized after a meeting with seven of the supplier's account and IT executives where there was a unanimous agreement on the mapping of the four sets of IT functionalities to the proprietary IT systems that had been implemented across all interfirm logistics relationships. Subsequently, from the vendor's technology archives, we obtained the mapping of the proprietary IT systems to each buyer and applied the coding scheme to determine the set of IT functionalities that were implemented in each interfirm relationship. Next, we validated from the transaction logs that the systems implemented in each interfirm relationship were actually being used very extensively to execute interfirm logistics transactions. The average IT utilization to execute interfirm logistics transactions was very high across all IT capability profiles (overall $\mu=80 \%$; Profile A: $\mu=75 \%$; Profile B: $\mu=87 \%$; Profile C: $\mu=78 \%$; Profile D: $\mu=93 \%$ (Table 5); the overall median and the median for each profile exceeded $99 \%$ of the logistics transactions executed using the set of IT functionalities implemented in a relationship) and showed no significant correlation with any of the four IT capability profiles. We were thus able to classify each interfirm relationship into one of the four interfirm IT capability profiles based on the set of IT functionalities that was implemented and actually being used to execute the interfirm logistics process (Table 5).

For our analysis, we defined IT capability Profile A as the baseline capability, and we created three dummy variables for the more sophisticated IT capability profiles. ${ }^{13}$ Prior to examining the effects of the IT capability profiles, we accounted for the effect of use of IT functionalities in the interfirm relationship on relational value. This was done by specifying IT utilization (measured as the percentage of the buyer's logistics transactions with the supplier executed using the implemented set of IT functionalities) as a control variable. This enabled us to consider the influence of utilization of the implemented set of IT functionalities on relational value prior to evaluating the effects of the interfirm IT capability profiles on relational value.

Interfirm communications for business development was measured as the aggregate number of visits and phone calls in the previous year between the buyer and the supplier's account executives. Interfirm communications for IT development was similarly measured as the aggregate number of visits or phone calls in the past year between the buyer and the supplier's $I T$ executives.

A natural question that emerges is whether the interfirm communications with senior executives reflect problems in the relationship rather than communications for relationship development. In our empirical context, the roles of the account executives and IT executives are defined to interact

\footnotetext{
${ }^{13} \mathrm{We}$ also coded IT capability profile sophistication as a rank-ordered variable and replicated all the analyses (see Appendix B). The results for the main and interaction effects are qualitatively the same with the profile-based approach, enabling us to detect differences in direct and interaction effects across the IT capability profiles.
} 
developmentally with buyers, and separate channels are established for routine problem handling. Also, we conducted a series of tests by obtaining additional data from the KDMs for a sample of firms: (1) a three-item measure for buyer's satisfaction with the supplier's problem resolution $(\mathrm{n}=383$; $\alpha=.85$ ); (2) frequency of problems experienced by the buyer $(\mathrm{n}=163)$; and (3) whether the buyer contacted the account executive when having problems $(n=1,103)$. We did not detect significant correlations among either of the two interfirm communications measures with either the frequency of problems experienced by the buyer or with the buyer's problem resolution satisfaction. Also, as a robustness check, we tested whether the account executive was contacted by the buyer for problems and whether the effects were stable. Along with the background on the roles of the account and IT executives in our setting, these results give us confidence that the communications among the supplier's account executives and IT executives with the buyers' executives are more likely to revolve around developmental or strategic issues as opposed to more operational or routine issues.

In terms of the control variables, buyer size was measured as the total number of employees. Transaction volume was measured as the total number of packages shipped per week. Supplier dependence on the buyer was computed as each buyer's contribution to the supplier's revenues relative to total revenues. Buyer satisfaction was measured using the mean of the KDM's response to three items: buyer's overall satisfaction with the supplier's services, buyer's appraisal of the supplier's performance relative to the buyer's expectations, and buyer's appraisal of the supplier's performance relative to an ideal supplier. Quality of servicing IT assets was measured based on the KDM's response on the supplier's performance in servicing the buyer's IT applications. Buyer logistics spending was measured as each buyer's annual shipping expenditures. Problem incidence experienced by the buyer was captured as a binary measure on whether the buyer had experienced logistics problems with the supplier in the last year or not. Finally, relationship duration (in years) was determined based on the date the buyer's account was created.

\section{Data Analysis and Results}

\section{Descriptive Statistics and Correlations}

The descriptive statistics and correlations are presented in Table 6. Based on NAICS codes, the top three industry categories were wholesale/retail trade, transportation, and warehousing (36\%); manufacturing (33\%); and information, finance and insurance, real estate and rental/leasing, and professional services (11\%). Relationship duration ranged from 1 to 21 years (mean $=12$ years). Buyer size ranged from 1 to 15,000 employees (mean $=131$ employees), and transaction volume ranged from 1 to 29,156 packages shipped per week (mean $=280$ packages per week).

\section{Results}

We safeguarded against common method bias by using data from four distinct archival sources (Podsakoff et al. 2003). Before conducting the analysis, we examined the distribution of each variable. Based on the variable distributions, we logtransformed buyer size, buyer spending, and the two communications variables. This is a typical procedure done for variables whose distribution has a long left tail (e.g., Lee and Chen 2009). We applied listwise deletion to the missing values resulting in an effective sample size of 1,659 responses for Models 1a-4a (Table 7) and 1,650 responses for Models $1 \mathrm{~b}-4 \mathrm{~b}$ (Table 8). We analyzed our data with multiple regression analysis with one-tailed tests, as we theorized the direction of all hypothesized effects (Miller and Miller 1999; Wooldridge 2009). ${ }^{14}$ We followed a three-step hierarchical procedure to test the theorized effects on share of wallet (SOW) and loyalty. We first included control variables (Model 1a, 1b), ${ }^{15}$ then added main effects (Model 2a, 2b), and then included interaction effects (Models 3a, 3b, 4a, 4b), as shown in Table 7 (for SOW) and Table 8 (for loyalty). ${ }^{16}$

We first mean-centered the continuous variables prior to computing their interaction terms to alleviate multicollinearity (Aiken and West 1991). We detected no severe multicollinearity issues based on variance inflation factors (VIF) or condition index (Hair et al. 2010). We also examined for independence of residuals (Cohen et al. 2003; Hair et al. 2010) and found the patterns of residuals across the four IT capability profiles to be similar. Ordinary least squares regression

\footnotetext{
${ }^{14}$ With the use of two-tailed tests, the effects of SCTD and ITCapa_D (Model 2) become marginally significant, while all other effects remain significant at $\mathrm{p}<.05$.

${ }^{15}$ Transaction volume was correlated with supplier's buyer dependence $(r=$ 0.97). As these two variables were highly correlated, only one of them could be retained as a control variable due to multicollinearity; the results were stable regardless of which of these two variables was retained.

${ }^{16}$ We conducted the Durbin-Wu-Hausmann test (Davidson and MacKinnon 1993) to test for endogeneity problems due to our specification of IT capabilities as predictors of SOW. Using the exogenous variables in the model, we estimated the residuals for each of the IT capability profiles and added them as predictors of SOW. We did not find any of the residual terms associated with the IT capability profiles to be significant, leading us to conclude that there are no endogeneity problems in our model estimates on SOW. We also did not detect any endogeneity problems in our model on loyalty.
} 
Table 6. Descriptive Statistics and Correlations ${ }^{\dagger}$

\begin{tabular}{|c|c|c|c|c|c|c|c|c|c|c|c|c|c|c|c|}
\hline Variables & 1 & 2 & 3 & 4 & 5 & 6 & 7 & 8 & 9 & 10 & 11 & 12 & 13 & 14 & 15 \\
\hline 1. Share of Wallet & - & & & & & & & & & & & & & & \\
\hline 2. Loyalty & 0.29 & - & & & & & & & & & & & & & \\
\hline 3. IT Capability Profile B & 0.05 & 0.00 & - & & & & & & & & & & & & \\
\hline 4. IT Capability Profile C & 0.01 & 0.00 & \begin{tabular}{|l|}
-0.67 \\
\end{tabular} & - & & & & & & & & & & & \\
\hline 5. IT Capability Profile D & 0.01 & 0.00 & \begin{tabular}{|l|}
-0.22 \\
\end{tabular} & -0.05 & - & & & & & & & & & & \\
\hline 6. Buyer Firm Size & -0.20 & -0.02 & -0.20 & 0.18 & 0.00 & - & & & & & & & & & \\
\hline $\begin{array}{l}\text { 7. Buyer Logistics } \\
\text { Spending }\end{array}$ & -0.17 & -0.03 & -0.03 & 0.12 & 0.06 & 0.23 & - & & & & & & & & \\
\hline $\begin{array}{l}\text { 8. Supplier's Buyer } \\
\text { Dependence }\end{array}$ & -0.01 & 0.03 & -0.07 & 0.10 & -0.01 & 0.18 & 0.18 & - & & & & & & & \\
\hline $\begin{array}{l}\text { 9. Quality of Servicing IT } \\
\text { Assets }\end{array}$ & 0.18 & 0.39 & 0.03 & -0.03 & -0.01 & 0.00 & -0.04 & 0.01 & - & & & & & & \\
\hline 10. Relationship Duration & 0.00 & 0.01 & 0.06 & 0.00 & -0.05 & 0.08 & 0.01 & -0.07 & 0.04 & - & & & & & \\
\hline 11. Incidence of Problems & 0.04 & 0.21 & 0.00 & -0.04 & -0.03 & 0.03 & -0.05 & 0.01 & 0.18 & -0.02 & - & & & & \\
\hline $\begin{array}{l}\text { 12. Relationship } \\
\text { Satisfaction }\end{array}$ & 0.16 & 0.63 & -0.03 & -0.02 & 0.00 & 0.05 & -0.01 & 0.02 & 0.47 & 0.01 & 0.27 & - & & & \\
\hline 13. IT Utilization & 0.06 & 0.01 & 0.13 & -0.08 & 0.03 & -0.16 & 0.04 & -0.15 & -0.03 & 0.07 & \begin{tabular}{|l|}
-0.03 \\
\end{tabular} & -0.01 & - & & \\
\hline $\begin{array}{l}\text { 14. Com. for Bus. } \\
\text { Development }\end{array}$ & -0.03 & 0.00 & -0.02 & 0.16 & 0.09 & 0.12 & 0.36 & 0.15 & 0.02 & 0.07 & -0.07 & 0.00 & 0.08 & - & \\
\hline $\begin{array}{l}\text { 15. Com. for IT } \\
\text { Development }\end{array}$ & 0.00 & 0.06 & -0.10 & 0.13 & 0.03 & 0.15 & 0.29 & 0.13 & 0.01 & -0.01 & \begin{tabular}{|l|}
-0.02 \\
\end{tabular} & 0.03 & 0.06 & 0.38 & - \\
\hline Mean & 83.5 & 8.6 & 0.8 & 0.1 & 0.01 & 130.7 & 395,956 & 0.0003 & 8.7 & 12.0 & 1.8 & 86.4 & 0.8 & 8.8 & 1.4 \\
\hline Standard Deviation & 23.8 & 1.7 & 0.4 & 0.3 & 0.1 & 587.9 & $7,036,179$ & 0.0009 & 1.7 & 4.8 & 0.4 & 12.5 & 0.3 & 9.9 & 6.0 \\
\hline
\end{tabular}

${ }^{\dagger} A$ correlation greater than 0.05 in absolute value is significant at the 0.05 level (two-tailed); $n=1,650$ (after listwise deletion).

is suitable for our analysis as our observations are temporally unrelated and do not represent how IT capability profiles evolve. While there is a logical progression in that IT functionalities augment other IT functionalities to help create more advanced IT capability profiles, a firm can implement any profile of IT capabilities at any time without having to implement an earlier IT capability profile. For example, a firm can readily implement Profile $\mathrm{C}$ without having had to previously implement Profile A or Profile B. ${ }^{17}$

In terms of SOW (Table 7), we observed that the adjusted $\Delta R^{2}$ between successive models was significant, providing evidence for the significance of the direct (Model 2a) and interaction effects (Model 3a) related to interfirm communications for business development with IT capabilities, which were added to the control variables (Model 1a). We did not observe any significant interaction effects between interfirm

\footnotetext{
${ }^{17}$ As a robustness check, we also coded the IT capability profiles as rankordered variables with progressive sophistication of the IT capability profiles (Appendix B), and the results were generally consistent for both SOW and loyalty.
}

communications for IT development with IT capability profiles (Model 4a).

In the controls model (Model 1a), buyer size and buyer's logistics spending had negative and significant (control) effects on SOW. As expected, supplier's buyer dependence, buyer satisfaction, quality of servicing IT assets, and IT utilization had positive and significant (control) effects on SOW. However, neither relationship duration nor industry type had a significant effect on SOW. We found positive and significant effects for all three IT capability profile dummy variables on SOW (Model 2a). We evaluated the relative impact of the IT capability profiles on SOW by comparing the regression coefficients of the IT capability profile dummies (Cohen et al. 2003, p. 641). We detected a significant difference between SOW for IT capability Profile A and Profile $\mathrm{B}(t=3.07)$ and a marginally significant difference between Profile B and Profile C $(t=1.41)$. However, we did not observe a significant difference in the relative effects between Profile C and Profile D. This effect may not have been detected because Profile D had only 1.6 percent of the buyers. These results provide evidence that each of the more sophis- 


\begin{tabular}{|c|c|c|c|c|c|c|c|c|}
\hline \multirow{2}{*}{$\begin{array}{ll} & \text { Variable } \\
\text { Intercept } & \\
\end{array}$} & \multicolumn{2}{|c|}{ Model 1a } & \multicolumn{2}{|c|}{ Model 2a } & \multicolumn{2}{|c|}{ Model 3a } & \multicolumn{2}{|c|}{ Model 4a } \\
\hline & $81.55^{* *}$ & (3.37) & $75.65^{* *}$ & (3.75) & $73.67^{* \star}$ & $(3.82)$ & $73.41^{* *}$ & $(3.82)$ \\
\hline \multicolumn{9}{|l|}{ Controls } \\
\hline Buyer Firm Size & $-2.66^{\star *}$ & $(0.42)$ & $-2.70^{* \star}$ & $(0.42)$ & $-2.65^{\star \star}$ & $(0.42)$ & $-2.64^{\star \star}$ & $(0.42)$ \\
\hline Buyer Logistics Spending & $-2.38^{* \star}$ & $(0.41)$ & $-2.71^{* *}$ & $(0.43)$ & $-2.65^{\star *}$ & $(0.43)$ & $-2.63^{* *}$ & $(0.43)$ \\
\hline Supplier's Buyer Dependence & $2161^{* \star}$ & $(670)$ & $1753^{\star \star}$ & $(687)$ & $1685^{\star \star}$ & $(688)$ & $1545^{*}$ & $(697)$ \\
\hline Quality of Servicing IT Assets & $1.69^{\star \star}$ & $(0.37)$ & $1.65^{\star \star}$ & $(0.36)$ & $1.66^{\star *}$ & $(0.36)$ & $1.66^{\star \star}$ & $(0.36)$ \\
\hline Relationship Duration & 0.00 & $(0.12)$ & -0.01 & $(0.12)$ & -0.01 & $(0.12)$ & -0.01 & $(0.12)$ \\
\hline Incidence of Problems & -0.95 & $(1.48)$ & -0.64 & $(1.47)$ & -0.66 & (1.47) & -0.64 & $(1.47)$ \\
\hline Satisfaction & $0.21^{\star \star}$ & $(0.05)$ & $0.22^{\star \star}$ & $(0.05)$ & $0.22^{\star \star}$ & $(0.05)$ & $0.22^{\star \star}$ & $(0.05)$ \\
\hline IT Utilization & $4.40^{\star \star}$ & $(1.85)$ & $3.87^{*}$ & $(1.86)$ & $3.81^{*}$ & $(1.86)$ & $3.70^{*}$ & $(1.86)$ \\
\hline NAICS Sector 31-33 & 0.38 & $(1.60)$ & 0.22 & $(1.59)$ & 0.24 & (1.59) & 0.25 & $(1.59)$ \\
\hline NAICS Sector 42-49 & 1.16 & $(1.55)$ & 1.26 & $(1.55)$ & $\overline{1.14}$ & $(1.55)$ & 1.15 & $(1.55)$ \\
\hline NAICS Sector 51-56 & -0.83 & $(2.12)$ & -0.71 & $(2.11)$ & -0.60 & (2.11) & -0.70 & $(2.11)$ \\
\hline \multicolumn{9}{|l|}{ Main Effects } \\
\hline $\begin{array}{l}\text { Interfirm Communications } \\
\text { for Business Development (ICBD) }\end{array}$ & & & -0.28 & $(0.72)$ & $-4.95^{\star *}$ & $(1.92)$ & $-5.66^{* *}$ & (1.99) \\
\hline $\begin{array}{l}\text { Interfirm Communications } \\
\text { for IT Development (ICTD) }\end{array}$ & & & $1.51^{*}$ & $(0.89)$ & $1.46^{*}$ & $(0.88)$ & $4.71^{*}$ & $(2.59)$ \\
\hline IT Capability Profile B (ITCapa_B) & & & $5.89^{\star \star}$ & $(1.92)$ & $8.00^{\star \star}$ & $(2.08)$ & $8.31^{* *}$ & $(2.09)$ \\
\hline IT Capability Profile C (ITCapa_C) & & & $9.44^{\star *}$ & $(2.43)$ & $10.86^{* \star}$ & (2.61) & $10.91^{* \star}$ & $(2.63)$ \\
\hline IT Capability Profile D (ITCapa_D) & & & $8.13^{*}$ & $(4.98)$ & 6.15 & $(5.68)$ & 7.16 & $(5.76)$ \\
\hline \multicolumn{9}{|l|}{ Interaction Effects } \\
\hline ICBD $\times$ ITCapa_B & & & & & $4.91^{* *}$ & $(2.03)$ & $5.93^{* *}$ & (2.13) \\
\hline ICBD $\times$ ITCapa_C & & & & & $6.23^{\star *}$ & $(2.62)$ & $6.14^{*}$ & $(2.77)$ \\
\hline ICBD $\times$ ITCapa_D & & & & & $10.97^{* *}$ & $(4.58)$ & $12.16^{\star *}$ & $(4.65)$ \\
\hline ICTD $\times$ ITCapa_B & & & & & & & $-4.20^{+}$ & $\begin{array}{l}(2.78) \\
\end{array}$ \\
\hline ICTD $\times$ ITCapa_C & & & & & & & -0.85 & $(3.32)$ \\
\hline ICTD $\times$ ITCapa_D & & & & & & & -8.70 & $(7.49)$ \\
\hline Adj. $R^{2}$ & \multicolumn{2}{|c|}{$\overline{0.096}$} & \multicolumn{2}{|c|}{0.103} & \multicolumn{2}{|c|}{0.107} & \multicolumn{2}{|c|}{$\overline{0.108}$} \\
\hline Adj. $R^{2}$ diff. & & & \multicolumn{2}{|c|}{$0.007^{* *}$} & \multicolumn{2}{|c|}{$0.004^{*}$} & \multicolumn{2}{|c|}{0.001} \\
\hline
\end{tabular}

†Unstandardized coefficients (standard errors) are shown (one-tailed). $\mathrm{N}=1659 . \quad\left({ }^{+} p<.10,{ }^{*} p<.05,{ }^{* *} p<.01\right)$

ticated interfirm IT capability profiles increases SOW: in comparison to Profile A, Profile B increases SOW more than Profile A (H1a), and Profile C increases SOW more than Profile B (H1b). However, we did not find significant evidence that Profile D increases SOW more than Profile C (H1c). We also observed that interfirm communications for business development did not have a significant direct effect on SOW. In contrast, interfirm communications for IT development had a significant effect on SOW, thereby supporting $\mathrm{H} 2 \mathrm{~b}$ but not $\mathrm{H} 2 \mathrm{a} .{ }^{18}$

We found a significant interaction effect between each of the

\footnotetext{
${ }^{18} \mathrm{We}$ also examined the quadratic effects of interfirm communications for business development and IT development (since excessive interactions could be counter-productive), and neither quadratic effect was significant.
}

three IT capability profile dummies and interfirm communications for business development on SOW, fully supporting H3a. Following Aiken and West (1991), we graphed these interaction effects to better understand the joint effects (Figure 2). The interaction between interfirm communications for business development was positive for the more sophisticated profiles (Profiles $\mathrm{C}$ and $\mathrm{D}$ ) but negative for the lowest profile (Profile A). The plots revealed that interfirm communications for business development must be accompanied by sophisticated IT capability profiles to create relational value; in the presence of less sophisticated ones (i.e., logistics automation), interfirm communications for business development had a negative effect on SOW. We did not observe significant interaction effects between any of the three IT capability profile dummies and interfirm communications for IT development, thus failing to support H3b. 


\begin{tabular}{|c|c|c|c|c|c|c|c|c|}
\hline \multirow{2}{*}{$\begin{array}{lr} & \text { Variable } \\
\text { Intercept } & \end{array}$} & \multicolumn{2}{|c|}{ Model 1b } & \multicolumn{2}{|c|}{ Model 2b } & \multicolumn{2}{|c|}{ Model 3b } & \multicolumn{2}{|c|}{ Model 4b } \\
\hline & $8.11^{\star \star}$ & $(0.19)$ & $7.94^{\star *}$ & $(0.21)$ & $7.91^{* *}$ & $(0.22)$ & $7.92^{\star *}$ & $(0.22)$ \\
\hline \multicolumn{9}{|l|}{ Controls } \\
\hline Buyer Firm Size & $-0.06^{* *}$ & $(0.02)$ & $-0.06^{*}$ & $(0.02)$ & $-0.06^{* *}$ & $(0.02)$ & $-0.06^{* *}$ & $(0.02)$ \\
\hline Buyer Logistics Spending & -0.01 & $(0.02)$ & -0.03 & $(0.02)$ & -0.03 & $(0.02)$ & -0.03 & $(0.02)$ \\
\hline Supplier's Buyer Dependence & $53.31^{+}$ & $(37.7)$ & 31.98 & (38.7) & 35.82 & $(38.9)$ & 40.62 & $(39.4)$ \\
\hline Quality of Servicing IT Assets & $0.11^{* \star}$ & $(0.02)$ & $0.11^{* *}$ & $(0.02)$ & $0.11^{* *}$ & $(0.02)$ & $0.11^{* *}$ & $(0.02)$ \\
\hline Relationship Duration & 0.00 & $(0.01)$ & 0.00 & $(0.01)$ & 0.00 & $(0.01)$ & 0.00 & $(0.01)$ \\
\hline Incidence of Problems & $0.19^{*}$ & $(0.08)$ & $0.20^{* *}$ & $(0.08)$ & $0.20^{*}$ & $(0.08)$ & $0.20^{* *}$ & $(0.08)$ \\
\hline Satisfaction & $0.08^{* \star}$ & $(0.00)$ & $0.08^{*}$ & $(0.00)$ & $0.08^{* *}$ & $(0.00)$ & $0.08^{* *}$ & $(0.00)$ \\
\hline IT Utilization & 0.11 & $(0.10)$ & 0.08 & $(0.11)$ & 0.07 & $\overline{(0.11)}$ & 0.07 & $(0.11)$ \\
\hline NAICS Sector 31-33 & $0.12^{+}$ & $(0.09)$ & $0.12^{+}$ & $(0.09)$ & $0.12^{+}$ & $(0.09)$ & $0.12^{+}$ & $(0.09)$ \\
\hline NAICS Sector $42-49$ & $0.12^{+}$ & $(0.09)$ & $0.12^{+}$ & $(0.09)$ & $0.12^{+}$ & $(0.09)$ & $0.12^{+}$ & $(0.09)$ \\
\hline NAICS Sector 51-56 & $0.24^{*}$ & $(0.12)$ & $0.25^{*}$ & $(0.12)$ & $0.25^{*}$ & $(0.12)$ & $0.26^{*}$ & $(0.12)$ \\
\hline \multicolumn{9}{|l|}{ Main Effects } \\
\hline $\begin{array}{l}\text { Interfirm Communications } \\
\text { for Business Development (ICBD) }\end{array}$ & & & -0.03 & $(0.04)$ & -0.12 & $(0.11)$ & -0.10 & $(0.11)$ \\
\hline $\begin{array}{l}\text { Interfirm Communications } \\
\text { for IT Development (ICTD) }\end{array}$ & & & $0.14^{* *}$ & $(0.05)$ & $0.13^{* *}$ & $(0.05)$ & 0.06 & $(0.15)$ \\
\hline IT Capability Profile B (ITCapa_B) & & & $0.19^{*}$ & $(0.11)$ & $0.22^{*}$ & $(0.12)$ & $0.22^{*}$ & $(0.12)$ \\
\hline IT Capability Profile C (ITCapa_C) & & & $0.25^{*}$ & $(0.14)$ & $0.30^{*}$ & $(0.15)$ & $0.30^{*}$ & $(0.15)$ \\
\hline IT Capability Profile D (ITCapa_D) & & & 0.14 & $(0.28)$ & 0.36 & $(0.32)$ & 0.33 & $(0.33)$ \\
\hline \multicolumn{9}{|l|}{ Interaction Effects } \\
\hline ICBD $\times$ ITCapa_B & & & & & 0.11 & $(0.11)$ & 0.09 & $(0.12)$ \\
\hline ICBD $\times$ ITCapa_C & & & & & 0.04 & $(0.15)$ & 0.05 & $(0.16)$ \\
\hline ICBD $\times$ ITCapa_D & & & & & -0.19 & $(0.26)$ & -0.21 & $(0.26)$ \\
\hline ICTD $\times$ ITCapa_B & & & & & & & 0.10 & $(0.16)$ \\
\hline ICTD $\times$ ITCapa_C & & & & & & & -0.01 & $(0.19)$ \\
\hline ICTD $\times$ ITCapa_D & & & & & & & 0.22 & $(0.42)$ \\
\hline Adj. $R^{2}$ & & 12 & & 14 & & 14 & & 14 \\
\hline Adj. $R^{2}$ diff. & & & & $02^{*}$ & & 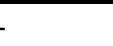 & & \\
\hline
\end{tabular}

†Unstandardized coefficients (standard errors) shown (one-tailed). $\mathrm{N}=1650 .\left({ }^{+} p<0.10,{ }^{*} p<0.05,{ }^{*} p<0.01\right.$ ) 

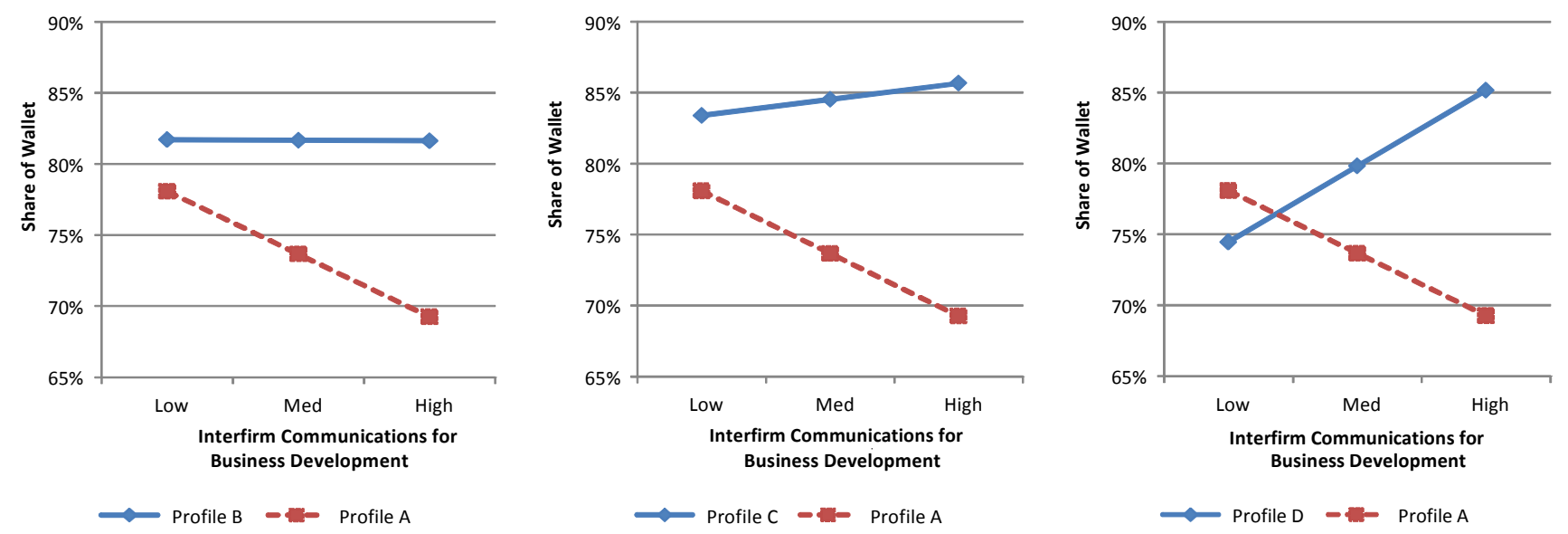

Note: Low, Med, and High refer to the level of interfirm communications for business development at -1 SD below the mean, at the mean, and at $+1 S D$ above the mean, respectively.

Figure 2. Interfirm Communications for Business Development and IT Capability Profiles

While we controlled for the supplier's dependence on the buyer (which correlates at $r=0.97$ with transaction volume), we evaluated the robustness of our results to subsamples based on increasing levels of transaction volume in the interfirm relationship (5, 10, and 20 packages/per week), and all results were stable across these subsamples.

In terms of variance explained in SOW, studies that rely on survey data explain between 20 and 30 percent of the variance, such as 19 percent of share of purchases (Magi 2003); studies with secondary (archival) data often explain less than 10 percent of the variance, such as 7 percent (Keiningham et al. 2003). Thus, adding the proposed ITrelated variables (e.g., interfirm IT capabilities and their interaction effects) improves the variance explained to 11percent. Taking into consideration that a 1 percent change in SOW moving from one supplier to another would result in an almost $\$ 1$ billion increase in competing revenues for a supplier, even a change of a few percentage points in SOW has substantial competitive implications. ${ }^{19}$

While SOW was our primary measure of relational value because it captures the proportion of the buyer's logistics budget allocated to the supplier, we replicated the analysis with buyer loyalty. We observed interfirm IT capability pro-

\footnotetext{
${ }^{19}$ The supplier firm in our study receives an average logistics spending of about $\$ 400,000$ from customers. By increasing its share of wallet by $1 \%$ by winning buyers from other suppliers, the total revenue increase could be estimated at about $\$ 1$ billion.
}

files and interfirm communications for IT development to have a similar direct effect on loyalty. However, unlike SOW, the interaction effects between interfirm IT capability profiles and interfirm communications for business development were nonsignificant.

\section{Discussion}

\section{Key Findings and Contributions}

This study has three key findings and makes three corresponding contributions (Table 9). First, it theorizes interfirm IT capability profiles as the implementation and use of a set of IT functionalities that combine with other resources to execute interfirm business processes. It theorizes that more sophisticated IT capability profiles are formed by implementing and using sets of progressively more advanced IT functionalities to manage the interdependencies in interfirm business processes, enabling interfirm relationships to cocreate higher relational value. In the context of the logistics industry, sophisticated IT capability profiles enable interfirm relationships to manage the interdependencies in the flow of physical goods, information, and finances across locations in the supply chain. Second, the effect of interfirm IT capability profiles on relational value is enhanced by interfirm communications for business development, surfacing interactions between these two determinants of relational value, but only when the IT capability profiles (Profiles B and C) are sufficiently sophisticated with relatively advanced IT function- 
Table 9. Summary of Key Findings and Contributions

\begin{tabular}{|c|c|c|}
\hline & Findings & Implications \\
\hline \multirow[b]{2}{*}{$\begin{array}{l}\text { H1 a-c: Higher } \\
\text { Sophistication of } \\
\text { Interfirm IT } \\
\text { Capability } \\
\text { Profiles } \rightarrow \\
\text { Relational Value }\end{array}$} & $\begin{array}{l}\text { IT functionalties, when implemented and } \\
\text { used in combination with other resources in } \\
\text { the interfirm logistics process (e.g., physical } \\
\text { goods, information, and finances across } \\
\text { locations), increase relational value (share } \\
\text { of wallet and loyalty). }\end{array}$ & $\begin{array}{l}\text { Progressively more advanced sets of IT functionalities } \\
\text { help form sophisticated interfirm IT capability profiles } \\
\text { that help manage the complex interdependencies in } \\
\text { interfirm business processes to cocreate relational } \\
\text { value. }\end{array}$ \\
\hline & $\begin{array}{l}\text { The set of IT functionalities used for logistics } \\
\text { synchronization and logistics integration, } \\
\text { respectively, form a more sophisticated IT } \\
\text { capability profile than the subset of these IT } \\
\text { functionalities used for logistics coordina- } \\
\text { tion; the set of IT functionalities used for } \\
\text { logistics coordination form a more sophisti- } \\
\text { cated IT capability profile than the subset of } \\
\text { IT functionalities implemented and used for } \\
\text { logistics automation. }\end{array}$ & $\begin{array}{l}\text { More sophisticated IT capability profiles can be formed } \\
\text { by implementing and using a greater number of } \\
\text { advanced IT functionalities to manage the interdepen- } \\
\text { dencies among activities in interfirm business process, } \\
\text { thereby creating the potential for greater relational } \\
\text { value with the addition of a higher number of } \\
\text { progressively more advanced IT functionalities. }\end{array}$ \\
\hline $\begin{array}{l}\text { H2: } \\
\text { Interfirm Com- } \\
\text { munications } \rightarrow \\
\text { Relational Value }\end{array}$ & $\begin{array}{l}\text { Interfirm communications for IT develop- } \\
\text { ment have a positive direct role in relational } \\
\text { value in interfirm logistics relationships, } \\
\text { while interfirm communications for business } \\
\text { development do not have a significant direct } \\
\text { effect. }\end{array}$ & $\begin{array}{l}\text { Interfirm communications for IT development create } \\
\text { relational value by promoting mutual understanding on } \\
\text { partners' evolving IT systems and IT infrastructure and } \\
\text { contextual knowledge on opportunities for IT to build } \\
\text { relational value. In contrast, interfirm communications } \\
\text { for business development do not have a significant } \\
\text { direct effect on relational value due to its countervailing } \\
\text { effects when IT capability profiles are more sophisti- } \\
\text { cated (positive effect) versus less sophisticated } \\
\text { (negative effect). }\end{array}$ \\
\hline \multirow{2}{*}{$\begin{array}{l}\text { H3: } \\
\text { Interfirm IT } \\
\text { Capability } \\
\text { Profiles } \times \\
\text { Interfirm Com- } \\
\text { munications } \rightarrow \\
\text { Relational Value }\end{array}$} & $\begin{array}{l}\text { More sophisticated interfirm IT capability } \\
\text { profiles (i.e., logistics coordination, logistics } \\
\text { integration, and logistics synchronization) } \\
\text { create greater relational value when } \\
\text { complemented by a more frequent contact } \\
\text { stream for interfirm communications on } \\
\text { business development. }\end{array}$ & $\begin{array}{l}\text { Interfirm communications for business development } \\
\text { promote mutual understanding of partners' objectives } \\
\text { and actions, as well as on the use of the IT } \\
\text { functionalities, enabling ongoing mutual adjustments in } \\
\text { leveraging the interfirm IT capability profile to manage } \\
\text { the interdependencies in their interfirm processes } \\
\text { toward cocreating relational value. }\end{array}$ \\
\hline & $\begin{array}{l}\text { Less sophisticated interfirm IT capability } \\
\text { profiles (i.e., logistics automation in the } \\
\text { logistics context) reduce relational value } \\
\text { when accompanied by interfirm communi- } \\
\text { cations for business development. }\end{array}$ & $\begin{array}{l}\text { While interfirm communications for business develop- } \\
\text { ment themselves promote mutual understanding of the } \\
\text { relationship's objectives and potential opportunities to } \\
\text { manage the interdependencies in the interfirm business } \\
\text { process to cocreate value, less sophisticated IT capa- } \\
\text { bility profiles impede the ability of interfirm relationships } \\
\text { to take advantage of these opportunities, thereby } \\
\text { adversely impacting the cocreation of relational value. }\end{array}$ \\
\hline
\end{tabular}


alities being used in the interfirm relationship. Finally, the study introduces and justifies share of wallet and loyalty as two major outcome measures that capture relational value cocreation. In making these three contributions, this study responds to Kohli and Grover's (2008) study and the call for papers of this special issue to shift the focus of IT business value studies from a traditional focus on examining the business value of IT alone at the individual firm level to a broader focus on studying the cocreation of value through IT at the interfirm relationship level.

\section{Implications for Theory}

This study has implications for (1) developing sophisticated interfirm IT capability profiles with the aid of progressively more advanced sets of IT functionalities toward cocreating relational value, (2) understanding direct and interaction effects between interfirm communications for business and IT development and interfirm IT capability profiles, and (3) the measurement of relational value in interfirm relationships.

\section{Developing Interfirm IT Capability Profiles toward Cocreating Business Value}

Since IT capabilities are major means for cocreating relational value (e.g., Banker et al. 2006; Bensaou 1997; Bharadwaj 2000; Choudhury 1997; Kohli and Grover 2008), this study fills a gap in the IS strategy literature by conceptualizing how IT functionalities, when implemented and used in combination with other resources, can help develop more sophisticated interfirm IT capability profiles. The proposed interfirm IT capability profiles are built on sets of IT functionalities that together with other resources (e.g., physical goods, information, finances) are used to manage the interdependencies of interfirm business processes. This study thus contributes to the literature by showing that profiles of interfirm IT capabilities create relational value in interfirm relationships through sets of IT functionalities that are implemented and used along with other resources to manage the complex interdependencies in interfirm processes.

Second, this study conceptualizes more sophisticated interfirm IT capability profiles as relying on a progressively larger set of more advanced IT functionalities that, when used together, can help manage the interdependencies of interfirm processes. Specifically, a set of four IT functionalities for interfirm logistics processes are proposed with progressively more advanced IT functionalities to enhance less advanced IT functionalities to facilitate key logistics processes, thus creating more sophisticated interfirm IT capability profiles. This has implications for the IT embeddedness view (Kohli and Grover
2008) in terms of how sets of IT functionalities can be implemented and used in an augmentive manner with other resources to help form sophisticated interfirm IT capabilities.

Third, while the IS strategy literature has focused primarily on a firm's own IT capabilities (viewing the firm as the unit of analysis) (e.g., Bala and Venkatesh 2007; Bharadwaj et al. 2007; Rai et al. 2006; Saraf et al. 2007), this study focuses on profiles of IT capabilities in interfirm relationships. Thus, it extends the IS strategy literature on IT capabilities by theorizing profiles of interfirm IT capabilities and their relative potential in creating relational value in the relationship.

Finally, extending Dyer and Singh's (1998) relational view focus on capabilities to achieve synergies among firms in an interfirm relationship as an important determinant of relational value, this study empirically shows that more sophisticated interfirm IT capability profiles enable an interfirm relationship to manage interdependenciees in interfirm business processes to cocreate relational value (or collaborative advantage for the extended enterprise).

\section{Interfirm IT Capability Profiles with Interfirm Communications}

This study also contributes to the IS literature by showing that interfirm IT capability profiles have a more substantial role in relational value when relying on interfirm communications for business development. We theorized that interfirm communications for business development reinforce the positive role of IT capability profiles in relational value. To our surprise, interfirm communications for business development coupled with less sophisticated interfirm IT capability profiles (logistics automation in the logistics context) negatively affected relational value (Figure 2). Only interfirm communications together with more sophisticated interfirm IT capability profiles (logistics coordination, integration, synchronization) amplify the positive effects of the interfirm IT capability profiles on relational value. This finding has notable implications for interfirm relationships in terms of having to implement sophisticated interfirm IT capability profiles to take advantage of interfirm communications for business development. In contrast, with less sophisticated interfirm IT capability profiles, the interfirm relationship is constrained in its ability to leverage communications for business development, thus reducing relational value cocreation.

Interfirm communications for IT development have a direct and positive effect on relational value; however, they do not reinforce the positive effect of the interfirm IT capability profiles on relational value. Our results imply that interfirm communications for business development are mainly useful 
to enhance the gains in relational value created by the interfirm IT capability profiles, while interfirm communications for IT development are primarily useful on their own to create relational value. These findings respond to the need for a deeper understanding of the contingencies that affect relational value (e.g., Im and Rai 2008; Klein and Rai 2009; Kohli and Grover 2008; Sabherwal and Chan 2001). Therefore, this study helps enhance our understanding of the complex interrelationships among IT capability profiles, interfirm communications, and relational value.

Finally, the interaction effects imply that it is insufficient to limit our attention to the direct determinants of relational value (Dyer and Singh 1998). Our study reinforces the importance of not treating IT as a foreign entity or as an isolated resource in cocreating relational value. Instead, our results indicate that IT capabilities are mechanisms to manage interdependencies with the aid of interfirm communications (for business development) to cocreate value. As such, our study contributes to the relational view by showing interaction effects between two direct determinants of relational value: sophisticated interfirm IT capability profiles and interfirm communications for business development. In doing so, this work not only contributes to the IS literature on complementarities between IT and (inter-)firm resources to create business value (Bharadwaj et al. 2007; Piccoli and Ives 2005; Wade and Hulland 2004), but it also extends our understanding of the contingencies that enhance the effect of interfirm IT capabilities on relational value (Sabherwal and Chan 2001).

\section{Measurement of Relational Value in Interfirm Relationships}

Our study also has implications for the measurement of relational value. First, we propose share of wallet and buyer loyalty as proxies of relational value. Kohli and Grover (2008) note that existing measures (e.g., ROI or cost savings) cannot adequately capture the business value from IT-based interfirm relationships, making it necessary to explore other measures of relational value. We build on the marketing literature that interfirm relationships can exhibit very different levels of success, and share of wallet and loyalty are appropriate measures to capture success at both the supplier's and the buyer's side (Bowman and Narayandas 2004). Share of wallet and loyalty are particularly appropriate measures of relational value in the logistics industry where both partners can reap huge benefits by developing a committed interfirm logistics relationship. Both measures reveal that interfirm IT capability profiles and communications for IT development enhance relational value directly. SOW reveals that comple- mentarities in relational value can be created by more sophisticated interfirm IT capability profiles together with interfirm communications for business development. This implies that a buyer's competitive preference of a supplier is shaped by synergies between IT capability profiles and interfirm communications in interfirm relationships. Taken together, these two proposed measures help answer Kohli and Grover's call for research to extend existing measures that capture relational value cocreation with the aid of IT.

\section{Implications for Practice}

Our study has practical implications for cocreating relational value in interfirm relationships. The results stress the role of building sophisticated interfirm IT capability profiles with the aid of advanced IT functionalities and other resources in building relational value both directly and indirectly by relying on interfirm communications. Interfirm communications for IT development directly contribute to relational value cocreation, implying that it is important to have interfirm communications to develop partner-specific learning related to IT systems, mutual understanding of IT infrastructure and IT applications, and joint exploration of the potential of IT innovations in interfirm processes. Interfirm communications for business development also support the role of IT capabilities in creating value, further supporting the importance of interfirm communications for business development. As such, it is important for firms to focus on both business and IT development by facilitating frequent and direct interactions among account and IT executives.

While the proposed effects on share of wallet and loyalty may seem small at first blush, a mere 1 percent increase in share of wallet by winning buyers from other suppliers can have sizeable effects, as the total logistics spending worldwide is about $\$ 370$ billion (Coyle et al. 2009). For example, the supplier in our study has about 300,000 active buyers with an average logistics spending of about $\$ 400,000$; by increasing its share of wallet by 1 percent relative to other suppliers, the total monetary value may exceed $\$ 1$ billion (in the United States alone). As such, our results have substantial practical implications for how logistics suppliers can cocreate value with their buyers.

\section{Limitations and Suggestions for Future Research}

A common issue with the use of secondary data to capture IT capabilities is the use of proxies (e.g., IT spending, existence of IT systems, implementation and use of IS applications), 
and it is not possible to have direct secondary measures of how well IT resources are being used. In contrast, studies that use primary data (e.g., Pavlou and El Sawy 2006) are able to capture the effective leveraging of IT functionalities by asking key respondents how well they believe IT functionalities are being leveraged. We have shown that the focal four sets of IT functionalities have been implemented in the interfirm logistics process, and we have strong evidence of the high utilization of these IT functionalities in interfirm relationships (Table 5). This corresponds to our definition of IT capability profiles being distinct from each other because the four sets of IT functionalities that are implemented and used in groupings of interfirm relationships are different.

Our coding and classification scheme (Table 5) only captures which IT functionalities have been implemented and used in each interfirm relationship, but it does not capture how effectively they are used. ${ }^{20}$ While we do not have direct observational data on how effectively IT functionalities are used in interfirm relationships, we do have evidence that the focal supplier has received many accolades in the logistics industry for enabling interfirm logistics processes to be executed effectively. Also, it is recognized in the industry for the quality of its IT functionalities. Besides having allocated significant resources for developing IT functionalities, the supplier has actively engaged lead buyers in the development of IT functionalities and has participated in various logistics technology-related groups to monitor trends and benchmark its IT functionalities against best practices and evolving IT requirements. The supplier has received numerous industry awards for being an innovator in using IT to execute logistics processes across industries. Nonetheless, future research could attempt to measure the effective use of IT functionalities.

Our approach of measuring IT capability profiles as the implementation and use of a set of IT functionalities is in response to the critique of the capabilities view as having tautological definitions of its key terms and operationalization failures (e.g., how effectively a process is undertaken can overlap with performance measures) (Williamson 1999, p. 1094). Accordingly, future research could explore other ways for measuring interfirm IT capabilities.

Following the relational view (Dyer and Singh 1998), this study assumed a causal link from interfirm IT capability pro-

\footnotetext{
${ }^{20}$ Our definition of IT capability profiles is consistent with Banker et al. (2006), Bharadwaj (2000), and Devraj and Kohli (2003) who do not specify effective use as part of their definitions of IT capabilities. Others who have used primary survey data have sometimes used the notion of effective use as part of their definition of IT capability.
}

files and interfirm communications to relational value. However, higher relational value encourages partners to enhance their interfirm IT capabilities by implementing new IT functionalities and increasing the contact stream of their communications, creating a continuous virtuous cycle that results in higher relational value over time. While our study did include the temporal precedence of the relational view and did show that our results were not subject to endogeneity problems, it did not include feedback loops, which can be examined by longitudinal research that explicitly incorporates the role of time in relational value cocreation.

This study focused on a set of four IT functionalities, which build on the implementation and use of each other in combination with other resources, to form interfirm IT capability profiles for interfirm logistics processes. While this parsimonious view of IT functionalities is appropriate for the logistics process, there are other specific IT functionalities in other industries that can support other business processes. IT functionalities can also relate to each other in more complex ways (e.g., substitute or compete with each other) to develop IT capability profiles. Moreover, there is a continuous development of advanced IT functionalities that could be implemented and used to enhance interfirm IT capabilities. Future research could examine how other IT functionalities can be combined with each other and with other resources in other industries and business contexts.

This study used share of wallet and loyalty as outcome measures of relational value, building on the marketing literature that linked share of wallet and loyalty to both supplier and buyer performance and profitability. Future research could assess the value of share of wallet and loyalty in other contexts. It should also evaluate additional measures that capture a supplier's response to a buyer by including measures of both the buyer's and supplier's responses and outcomes to reveal insights on symmetries or asymmetries between partners and relational value cocreation initiatives.

This study was based on over 2,000 buyers of one of the world's largest logistics suppliers. While our approach gave us rich insights in terms of contextually understanding the single supplier and its diverse relationships across multiple buyers, natural controls with respect to the supplier's characteristics, contractual governance, and rich access to data from four archival sources, it has its shortcomings. Future research could focus on other industries and attempt to capture heterogeneity in suppliers. It could also examine how variations in contracts (e.g., incentives, value appropriation) can enable or prevent the embedding of IT functionalities in the process of interfirm relationships. 


\section{Conclusion}

According to Kohli and Grover (2008, p. 28), "if IT is used as a tool or is instrumental in creating a product to cocreate business value, then it falls within the domain of IT value research." This study answers the call for a next generation of studies on the business value of IT that focus on cocreating relational value with the aid of IT rather than focusing only on IT value. Therefore, this study represents an important extension to our understanding of the mechanisms by which interfirm IT capability profiles and interfirm communications both individually and jointly support the cocreation of relational value in interfirm relationships.

\section{Acknowledgments}

We thank the senior editors, Varun Grover and Rajiv Kohli, the associate editor, Indranil Bardhan, and the three anonymous reviewers for their constructive comments and valuable suggestions. We also thank the executives at the logistics firm and its customers for sharing their perspectives in numerous discussions and for providing us access to the data.

\section{References}

Aiken, L. S., and West, S. G. 1991. Multiple Regression: Testing and Interpreting Interactions, London: Sage Publications.

Amit, R., and Schoemaker, P. J. H. 1993. "Strategic Assets and Organizational Rent," Strategic Management Journal (14:1), pp. 33-46.

Anderson, E., and Mittal, V. 2000. "Strengthening the SatisfactionProfit Chain," Journal of Services Research (3:2), pp. 107-120.

Anderson, E., and Weitz, B. 1992. "The Use of Pledges to Build and Sustain Commitment in Distribution Channels," Journal of Marketing Research (29:1), pp. 18-34.

Anderson, J. C., and Narus, J. A. 1984. "A Model of the Distributor's Perspective of Distributor-Manufacturer Working Relationships," Journal of Marketing (48:4), pp. 62-74.

Anderson, J. C., and Narus, J. A. 1990. "A Model of Distributor Firm and Manufacturer Firm Working Partnerships," Journal of Marketing (54:1), pp. 42-58.

Armstrong \& Associates, Inc. 2009. “A\&A's Top 50 Global ThirdParty Logistics Provider (3PL) List," West Allis, WI (available at http://www.3plogistics.com/Top_50_Global_3PLs.htm).

Bakos, J. Y., and Brynjolfsson, E. 1993. "Information Technology, Incentives, and the Optimal Number of Suppliers," Journal of Management Information Systems (10:2), pp. 37-53.

Bala, H., and Venkatesh, V. 2007. "Assimilation of Interorganizational Business Process Standards," Information Systems Research (18:3), pp. 340-362.

Banker, R. D., Bardhan, I. R., Chang, H., and Lin, S. 2006. "Plant Information Systems, Manufacturing Capabilities, and Plant Performance,” MIS Quarterly (30:2), pp. 315-337.
Barney, J. 1991. "Firm Resources and Sustained Competitive Advantage," Journal of Management (17), pp. 99-120.

Baumann, C., Burton, S., and Elliot, G. 2005. "Determinants of Customer Loyalty and Share of Wallet in Retail Banking," Journal of Financial Services Market (9:3), pp. 231-248.

Bearden, W., Malhotra, M., and Uscátegui, K. 1998. "Customer Contact and the Evaluation of Service Experiences: Propositions and Implications for the Design of Services," Psychology and Marketing (15:8), pp. 793-809.

Bensaou, M. 1997. "Interorganizational Cooperation: The Role of Information Technology an Empirical Comparison of U.S. and Japanese Supplier Relations," Information Systems Research (8:2), pp. 107-124.

Bensaou, M., and Venkatraman, N. 1995. "Configurations of Interorganizational Relationships: A Comparison between U.S. and Japanese Automakers," Management Science (41:9), pp. 1471-1492.

Berry, L. L. 1980. "Service Marketing Is Different," Business, May-June, pp. 24-29.

Bharadwaj, A. S. 2000. "A Resource-Based Perspective on Information Technology Capability and Firm Performance: An Empirical Investigation," MIS Quarterly (24:1), pp. 169-196.

Bharadwaj, S., Bharadwaj, A., and Bendoly, E. 2007. "The Performance Effects of Complementarities between Information Systems, Marketing, Manufacturing, and Supply Chain Processes," Information Systems Research (18:4), pp. 437-453.

Bingham, C., Eisenhardt, K., and Furr, N. 2007. "What Makes a Process a Capability? Heuristics, Strategy, and Effective Capture of Opportunities," Strategic Entrepreneurship Journal (1:1-2), pp. 27-47.

Bowen, D. E. 1986. "Managing Customers as Human Resources in Service Organizations," Human Resource Management (25:3), pp. 371-383.

Bowen, D. E., and Jones, G. R. 1986. "Transaction Cost Analysis of Service Organization-Customer Exchange," Academy of Management Review (11:2), pp. 428-441.

Bowen, D. E., Siehl, C., and Schneider, B. 1989. “A Framework for Analyzing Customer Service Orientations in Manufacturing," Academy of Management Review (14:1), pp. 75-95.

Bowman, D., and Narayandas, D. 2004. "Linking Customer Management Effort to Customer Profitability in Business Markets," Journal of Marketing Research (41:4), pp. 433-447.

Callarisa Fiol, L. J., Bigne Alcañiz, E., Moliner Tena, M. A., and García, J. S. 2009. "Customer Loyalty in Clusters: Perceived Value and Satisfaction as Antecedents," Journal of Business-toBusiness Marketing (16:3), pp. 276-316.

Cannon, J., and Perreault, W. 1999. "Buyer-Seller Relationships in Business Markets," Journal of Marketing Research (36:4), pp. 439-460.

Carte, T. A., and Russell, C. J. 2003. "In Pursuit of Moderation: Nine Common Errors and Their Solutions," MIS Quarterly (27:3), pp. 479-501.

Chan, Y. E. 2002. "Why Haven't We Mastered Alignment? The Importance of the Informal Organization Structure," MIS Quarterly Executive (1:2), pp. 97-112. 
Chase, R. B. 1978. "Where Does the Customer Fit in a Service Operation?," Harvard Business Review (56:6), pp. 137-142.

Chase, R. B. 1981. "The Customer Contact Approach to Services: Theoretical Bases and Practical Extensions," Operations Research (29:4), pp. 698-706.

Chase, R. B., and Tansik, D. A. 1983. "The Customer Contact Model for Organization Design," Management Science (29:9), pp. 1037-1050.

Child, J. 1987. "Information Technology, Organization, and the Response to Strategic Challenges," California Management Review (30:1), pp. 33-50.

Choudhury, V. 1997. "Strategic Choices in the Development of Interorganizational Information Systems," Information Systems Research (8:1), pp. 1-24.

Choudhury, V., and Sabherwal, R. 2003. "Portfolios of Control in Outsourced Software Development Projects," Information Systems Research (14:3), pp. 291-314.

Cohen, J., West, S. G., Aiken, L., and Cohen, P. 2003. Applied Multiple Regression/Correlation Analysis for the Behavioral Sciences ( ${ }^{\text {rd }}$ ed.), Mahwah, NJ: Lawrence Erlbaum Associates.

Collier, D. A. 1983. "The Service Sector Revolution: The Automation of Services," Long Range Planning (16:6), pp. 10-20.

Cooil, B., Keiningham, T. L., Aksoy, L., and Hsu, M. 2007. “A Longitudinal Analysis of Customer Satisfaction and Share of Wallet: Investigating the Moderating Effect of Customer Characteristics," Journal of Marketing (71), pp. 67-83.

Cortina, J. M. 1993. "Interaction, Nonlinearity, and Multicollinearity: Implications for Multiple Regression," Journal of Management (19:4), pp. 915-922.

Coyle, J. J., Langley, C. J., Gibson, B. J., Novack, R. A., and Bardi, E. J. 2009. Supply Chain Management: A Logistics Perspective ( $8^{\text {th }}$ ed.), Mason, $\mathrm{OH}$ : Cengage Learning.

Cunningham, R. M. 1956. "Brand Loyalty: What, Where, How Much?," Harvard Business Review (34:1), pp. 116-128.

D'Adderio, L. 2001. "Crafting the Virtual Prototype: How Firms Integrate Knowledge and Capabilities across Organizational Boundaries," Research Policy (30:9), pp. 1409-1424.

Davidson, R., and MacKinnon, J. G. 1993. Estimation and Inference in Econometrics, New York: Oxford University Press.

Devaraj, S., and Kohli, R. 2003. "Performance Impacts of Information Technology: Is Actual Usage the Missing Link?," Management Science (49:3), pp. 273-289.

Doney, P. M., and Cannon, J. R. 1997. "An Examination of the Nature of Trust in Buyer-Seller Relationships," Journal of Marketing (61), pp. 35-51.

Doz, Y. L. 1987. "Technology Partnerships between Larger and Smaller Firms: Some Critical Issues," International Studies of Management and Organization (17:4), pp. 31-58.

Dwyer, F. R., Schurr, P. H., and Oh, S. 1987. "Developing Buyer-Supplier Relationships," Journal of Marketing (51:2), pp. 11-27.

Dyer, J. 1997. "Effective Interfirm Collaboration: How Firms Minimize Transaction Costs and Maximize Transaction Value," Strategic Management Journal (18:7), pp. 535-556.

Dyer, J. H. 2000. Collaborative Advantage: Winning through Extended Enterprise Supplier Networks, New York: Oxford University Press.
Dyer, J. H., and Singh, H. 1998. "The Relational View: Cooperative Strategy and Sources of Interorganizational Competitive Advantage," Academy of Management Review (23:4), pp. 660-679.

Earl, M. 2001. “'Knowledge Management Strategies: Toward a Taxonomy," Journal of Management Information Systems (18:1), pp. 215-233.

Froehle, C., and Roth, A. 2004. "New Measurement Scales for Evaluating Perceptions of the Technology-Mediated Customer Service Experience," Journal of Operations Management (22:1), pp. 1-21.

Ganesan, S. 1994. "Determinants of Long-Term Orientation in Buyer-Seller Relationships," Journal of Marketing (58:2), pp. 50-69.

Garland, R. 2004. "Share of Wallet's Role in Customer Profitability," Journal of Financial Services Marketing (8:3), pp. 259-268.

Gefen, D., and Ridings, C. M. 2002. "Implementation Team Responsiveness and User Evaluation of Customer Relationship Management: A Quasi-Experimental Design Study of Social Exchange Theory," Journal of Management Information Systems (19:1), pp. 47-69.

Gomez, M., McLaughlin, E., and Wittink, D. 2004. "Customer Satisfaction and Retail Sales Performance: An Empirical Investigation," Journal of Retailing (80:4), pp. 265-278.

Grant, R. M. 1996. "Prospering in Dynamically-Competitive Environments: Organizational Capability as Knowledge Integration," Organization Science (7:4), pp. 375-387.

Gulati, R. 1995. "Does Familiarity Breed Trust: The Implications of Repeated Ties for Contractual Choices in Alliances," Academy of Management Journal (38:1), pp. 85-112.

Gulati, R., and Singh, H. 1998. "The Architecture of Cooperation: Managing Coordination Costs and Appropriation Concerns in Strategic Alliances," Administrative Science Quarterly (43:4), pp. 781-814.

Hair, J. F., Black, W. C., Babin, B. J., and Anderson, R. 2010. Multivariate Data Analysis ( $7^{\text {th }}$ ed.), Upper Saddle River, NJ: Prentice Hall.

Henderson, R. M., and Clark, K. B. 1990. “Architectural Innovation: The Reconfiguration of Existing Product Technologies and the Failure of Established Firms," Administrative Science Quarterly (35:1), pp. 9-32.

Holm, D. B., Eriksson, K., and Johanson, J. 1999. "Creating Value through Mutual Commitment to Business Network Relationships," Strategic Management Journal (20:5), pp. 467-486.

Holweg, M., and Pil, F. 2008. "Theoretical Perspectives on the Coordination of Supply Chains," Journal of Operations Management (26:3), pp. 389-406.

IBM Research. 2004. "Services Science: A New Academic Discipline," (available at http://www.almaden.ibm.com/asr/ resources/facsummit.pdf).

Im, G. Y., and Rai, A. 2008. "Knowledge Sharing Ambidexterity in Long-Term Interorganizational Relationships," Management Science (54:7), pp. 1281-1296.

Jap, S. D. 2001. "Perspectives on Joint Competitive Advantages in Buyer-Supplier Relationships," International Journal of Research in Marketing (18:1-2), pp. 19-35. 
Jones, T. O., and Sasser, W. E. 1995. "Why Satisfied Customers Defect," Harvard Business Review (73:6), pp. 88-91.

Joshi, A. W. 2009. "Continuous Supplier Performance Improvement: Effects of Collaborative Communication and Control," Journal of Marketing (73:1), pp. 133-150.

Kale, P., Dyer, J. H., and Singh, H. 2002. "Alliance Capability, Stock Market Response, and Long Term Alliance Success: The Role of the Alliance Function," Strategic Management Journal (23:8), pp. 747-767.

Kanter, R. 1994. "Collaborative Advantage: The Art of Alliances," Harvard Business Review (72), pp. 96-108.

Keiningham, T. L., Perkins-Munn, T., Aksoy, L., and Estrin, D. 2005. "Does Customer Satisfaction Lead to Profitability? The Mediating Role of Share of Wallet," Managing Service Quality (15:2), pp. 172-181.

Keiningham, T. L., Perkins-Munn, T., and Evans, D. 2003. "The Impact of Customer Satisfaction on Share-of-Wallet in a Business-to-Business Environment," Journal of Service Research (6:1), pp. 37-50.

Kellermann, K. 1992. "Communication: Inherently Strategic and Primarily Automatic," Communication Monographs (59:3), pp. 288-300.

Kellogg, D. L., and Chase, R. B. 2005. "Constructing an Empirically Derived Measure for Customer Contact," Management Science (41:11), pp. 1734-1749.

Klein, R., and Rai, A. 2009. "Interfirm Strategic Information Flows in Logistics Supply Chain Relationships," MIS Quarterly (33:4), pp. 735-762.

Klein, R., Rai, A., and Straub, D. W. 2007. "Competitive and Cooperative Positioning in Supply Chain Logistics Relationships," Decision Sciences (38:4), pp. 611-646.

Kohli, R., and Devaraj, S. 2003. "Measuring Information Technology Payoff: A Meta-Analysis of Structural Variables in Firm-Level Empirical Research," Information Systems Research (14:2), pp. 127-145.

Kohli, R., and Grover, V. 2008. "Business Value of IT: An Essay on Expanding Research Directions to Keep up with the Times," Journal of the Association for Information Systems (9:1), pp. 23-39.

Kotabe, M., Martin, X., and Domoto, H. 2003. "Gaining from Vertical Partnerships: Knowledge Transfer, Relationship Duration, and Supplier Performance Improvement in the U.S. and Japanese Automotive Industries," Strategic Management Journal (24:4), pp. 293-316.

Koza, M. P., and Lewin, A. Y. 1998. "The Co-Evolution of Strategic Alliances," Organization Science (9:3), pp. 255-264.

Lane, P. J., and Lubatkin, M. 1998. "Relative Absorptive Capacity and Interorganizational Learning," Strategic Management Journal (19:5), pp. 461-477.

Lee, R. P., and Chen, Q. M. 2009. “The Immediate Impact of New Product Introductions on Stock Price: The Role of Firm Resources and Size," Journal of Product Innovation Management (26:1), pp. 97-107.

Lewis, M., Rai, A., Forquer, D., and Quinter, D. 2007. "UPS and HP: Value Creation through Supply Chain Partnerships," Ivey Case Publishing.
Lorange, P., and Roos, J. 1993. Strategic Alliance: Formation, Implementation, and Control, Englewood Cliff, NJ: Prentice Hall.

Lovelock, C., and Wirtz, J. 1984. Services Marketing, Englewood Cliffs, NJ: Prentice Hall.

Loveman, G. W. 1998. "Employee Satisfaction, Customer Loyalty, and Financial Performance: An Empirical Examination of the Service Profit Chain in Retail Banking," Journal of Service Research (1), pp. 18-31.

MacNeil, I. 1980. The New Social Contract: An Inquiry into Modern Contractual Relations, New Haven, CT: Yale University Press.

Magi, A. W. 2003. "Share of Wallet in Retailing: The Effects of Customer Satisfaction, Loyalty Cards and Shopper Characteristics," Journal of Retailing (79:2), pp. 97-106.

Mata, F. J., Fuerst, W. L., and Barney, J. B. 1995. "Information Technology and Sustained Competitive Advantage: A ResourceBased Analysis," MIS Quarterly (19:4), pp. 487-505.

Miller, I., and Miller, M. 1999. John E. Freund's Mathematical Statistics $\left(6^{\text {th }}\right.$ ed.), Upper Saddle River, NJ: Prentice Hall.

Mills, P. 1986. Managing Service Industries: Organizational Practices in a Postindustrial Economy, Cambridge, MA: Ballinger.

Mishra, A., Konana, P., and Barua, A. 2007. “Antecedents and Consequences of Internet Use in Procurement: An Empirical Investigation of U.S. Manufacturing Firms," Information Systems Research (18:1), pp. 103-120.

Mohr, J. J., Fisher, R. J., and Nevin, J. R. 1996. "Collaborative Communication in Interfirm Relationships: Moderating Effects of Integration and Control," Journal of Marketing (60:3), pp. 103-115.

Mohr, J. J., and Nevin, J. R. 1990. "Communication Strategies in Marketing Channels: A Theoretical Perspective," Journal of Marketing (54:4), pp. 36-51.

Morgan, R. M., and Hunt, S. D. 1994. "The Commitment-Trust Theory of Relationship Marketing," Journal of Marketing (58:3), pp. 20-38.

Mowery, D. C., Oxley, J. E., and Silverman, B. S. 1996. "Strategic Alliances and Interfirm Knowledge Transfer," Strategic Management Journal (17), pp. 77-91.

Oliver, R. L. 1980. "A Cognitive Model of the Antecedents and Consequences of Satisfaction Decisions," Journal of Marketing Research (17:4), pp. 460-469.

O’Marah, K., and Hofman, D. 2010. "The AMR Supply Chain Top 25 for 2010," Gartner Group, Stamford, CT.

Palmatier, R. W., Scheer, L. K., Evans, K. R., and Arnold, T. J. 2008. "Achieving Relationship Marketing Effectiveness in Business-to-Business Exchanges," Journal of the Academy of Marketing Science (36:2), pp. 174-190.

Paul, C. 2009. "Whither Strategic Communication? A Survey of Current Proposals and Recommendations," RAND Corporation, Santa Monica, CA.

Paulraj, A., Lado, A. A., and Chen, I. J. 2008. "InterOrganizational Communication as a Relational Competency: Antecedents and Performance Outcomes in Collaborative BuyerSupplier Relationships," Journal of Operations Management (26:1), pp. 45-64. 
Pavlou, P., and El Sawy, O. 2006. "From IT Leveraging Competence to Competitive Advantage in Turbulent Environments: The Case of New Product Development," Information Systems Research (17:3), pp. 198-227.

Perkins-Munn, T., Aksoy, L., Keiningham, T. L., and Estrin, D. 2005. "Actual Purchase as a Proxy for Share of Wallet," Journal of Service Research (7:3), pp. 245-256.

Piccoli, G., and Ives, B. 2005. "Review: IT-Dependent Strategic Initiatives and Sustained Competitive Advantage: A Review and Synthesis of the Literature," MIS Quarterly (29:4), pp. 747-776.

Podsakoff, P., MacKenzie, S., Lee, J., and Podsakoff, N. 2003. "Common Method Biases in Behavioral Research: A Critical Review of the Literature and Recommended Remedies," Journal of Applied Psychology (88:5), pp. 879-903.

Powell, W. W., Koput, K. W., and Smith-Doerr, L. 1996. "Interorganizational Collaboration and the Locus of Innovation: Networks of Learning in Biotechnology," Administrative Science Quarterly (41:1), pp. 116-145.

Primo, M. A. M., and Amundson, S. D. 2002. "An Exploratory Study of the Effects of Supplier Relationships on New Product Development Outcomes," Journal of Operations Management (20:1), pp. 33-52.

Rai, A., Brown, P., and Tang, X. 2009. "Organizational Assimilation of Electronic Procurement Innovations," Journal of Management Information Systems (26:1), pp. 257-296.

Rai, A., Im, G., and Hornyak, R. 2009. "How CIOs Can Align IT Capabilities for Supply Chain Relationships," MIS Quarterly Executive (8:1), pp. 9-18.

Rai, A., Patnayakuni, R., and Seth, N. 2006. "Firm Performance Impacts of Digitally Enabled Supply Chain Integration Capabilities," MIS Quarterly (30:2), pp. 225-246.

Rai, A., and Sambamurthy, V. 2006. "Editorial Notes: The Growth of Interest in Services Management: Opportunities for Information Systems Scholars," Information Systems Research (17:4), pp. 327-331.

Rapert, M. I., Velliquette, A., and Garretson, J. A. 2002. "The Strategic Implementation Process: Evoking Strategic Consensus through Communication," Journal of Business Research (55:4), pp. 301-310.

Ray, G., Muhanna, W. A., and Barney, J. B. 2005. "Information Technology and the Performance of the Customer Service Process: A Resource-Based Analysis," MIS Quarterly (29:4), pp. 625-652.

Reinartz, W., Thomas, J. S., and Kumar, V. 2005. "Balancing Acquisition and Retention Resources to Maximize Customer Profitability," Journal of Marketing (69:1), pp. 63-79.

Rust, R. T., and Zaborik, A. J. 1993. "Customer Satisfaction, Customer Retention, and Market Share," Journal of Retailing (69:2), pp. 193-215.

Sabherwal, R., and Chan, Y. 2001. "Alignment between Business and IS Strategies: A Study of Prospectors, Analyzers, and Defenders," Information Systems Research (12:1), pp. 11-33.

Sabherwal, R., and Kirs, P. 1994. "The Alignment between Organizational Critical Success Factors and Information Technology Capability in Academic Institutions," Decision Sciences (25), pp. 301-301.
Sambamurthy, V., Bharadwaj, A., and Grover, V. 2003. "Shaping Agility through Digital Options: Reconceptualizing the Role of Information Technology in Contemporary Firms," MIS Quarterly (27:2), pp. 237-263.

Saraf, N., Langdon, C., and Gosain, S. 2007. "IS Application Capabilities and Relational Value in Interfirm Partnerships," Information Systems Research (18:3), pp. 320-339.

Simchi-Levi, D., Kamisnsky, P., and Simchi-Levi, E. 2008. Designing and Managing the Supply Chain: Concepts, Strategies and Case Studies ( $3^{\text {rd }}$ ed.), Boston: Irwin/McGraw Hill.

Subramani, M. 2004. "How Do Suppliers Benefit from Information Technology Use in Supply Chain Relationships?," MIS Quarterly (28:1), pp. 45-73.

Takeishi, A. 2001. "Bridging Inter- and Intra-Firm Boundaries: Management of Supplier Involvement in Automobile Product Development," Strategic Management Journal (22:5), pp. 403-433.

Tanriverdi, H. 2005. "Information Technology Relatedness, Knowledge Management Capability, and Performance of Multibusiness Firms," MIS Quarterly (29:2), pp. 311-334.

Tanriverdi, H. 2006. "Performance Effects of Information Technology Synergies in Multibusiness Firms," MIS Quarterly (30:1), pp. 57-77.

Tanriverdi, H., and Venkatraman, N. 2005. "Knowledge Relatedness and the Performance of Multibusiness Firms," Strategic Management Journal (26:2), pp. 97-119.

Venkatesan, R., and Kumar, V. 2004. "A Customer Lifetime Value Framework for Customer Selection and Resource Allocation Strategy," Journal of Marketing (68:4), pp. 106-125.

Victor, B., and Blackburn, R. S. 1987. "Interdependence: An Alternative Conceptualization," Academy of Management Review (12:3), pp. 486-498.

Wade, M., and Hulland, J. 2004. "Review: The Resource-Based View and Information Systems Research: Review, Extension, and Suggestions for Future Research," MIS Quarterly (28:1), pp. 107-142.

Weick, K. E. 1976. "Educational Organizations as Loosely Coupled Systems," Administrative Science Quarterly (21:1), pp. $1-19$.

Williamson, O. E. 1999. "Strategy Research: Governance and Competence Perspective," Strategic Management Journal (20:12), pp. 1087-1108.

Wind, Y. 1970. "Industrial Source Loyalty,” Journal of Marketing Research (7:4), pp. 450-457.

Wooldridge, J. 2009. Introductory Econometrics: A Modern Approach ( $4^{\text {th }}$ ed.), Mason, OH: South-Western.

Zajac, E. J., and Olsen, C. P. 1993. "From Transaction Cost to Transactional Value Analysis: Implications for the Study of Interorganizational Strategies," Journal of Management Studies (30:1), pp. 131-145.

Zhu, K., and Kraemer, K. L. 2002. "E-Commerce Metrics for NetEnhanced Organizations: Assessing the Value of E-Commerce to Firm Performance in the Manufacturing Sector," Information Systems Research (13:3), pp. 275-295. 


\section{About the Authors}

Arun Rai is Regents' Professor and the Harkins Chair in the Center for Process Innovation and the Department of Computer Information Systems at the Robinson College of Business, Georgia State University. His research has examined how firms can leverage information technologies in their strategies, interfirm relationships, and processes, and how systems can be successfully developed and implemented. His articles have appeared in Management Science, MIS Quarterly, Information Systems Research, Journal of Management Information Systems, Journal of Operations Management and other journals. He serves, or has served, as a senior editor at Information Systems Research and Journal of Strategic Information Systems and as an associate editor at Information Systems Research, Management Science, Journal of MIS and MIS Quarterly. He was named Fellow of the Association for Information Systems in 2010 in recognition for outstanding contributions to the Information Systems discipline.

Paul A. Pavlou is an associate professor and a Stauffer Senior Research Fellow at the Fox School of Business at Temple University. He received his Ph.D. from the University of Southern California in 2004. His research focuses on digital business strategy, electronic commerce, online auctions, and neuroIS. His work has been cited over 2,000 times by the Social Science Citation Index and over 7,000 times by Google Scholar. Paul won the ISR Best Paper award in 2007, the 2006 IS Publication of the Year award, and the Best Doctoral Dissertation award of the 2004 Inter- national Conference on Information Systems. He also received the 2009 Management Science Meritorious service award and the 2003 MIS Quarterly Reviewer of the Year award.

Ghiyoung Im is a visiting assistant professor in the Department of Computer Information Systems at the University of Louisville. He received his Ph.D. from Georgia State University and a M.S. from New York University's Stern School of Business. His research interests center on IT-enabled organizational learning, knowledge management, and coordination in interorganizational relationships, and their implications for firm strategy and supply chain management. His research has appeared in Management Science, Journal of the Association for Information Systems, Information Systems Journal, and The DATA BASE for Advances in Information Systems, among others.

Steve Du is an associate of the Center for Process Innovation at Georgia State University. He received his Ph.D. in Computer Information Systems from Georgia State University, an MBA from the University of California, Berkeley, an MS from Stanford University and a BS in Electrical Engineering from Princeton University. He has experience in the software industry as a product manager and an applications consultant. His current research focuses on interorganizational information systems. Steve's research has been published in Decision Support Systems, Journal of Informatics Education Research, and Journal of Information Systems Education. 


\title{
INTERFIRM IT CAPABILITY PROFILES AND COMMUNICATIONS FOR COCREATING RELATIONAL VALUE: EVIDENCE FROM THE LOGISTICS INDUSTRY
}

\author{
Arun Rai \\ Center for Process Innovation and Department of Computer Information Systems, Robinson College of Business, \\ Georgia State University, Atlanta, GA 30303 U.S.A. \{arunrai@gsu.edu\}
}

Paul A. Pavlou

Fox School of Business, Temple University, Philadelphia, PA 19122 U.S.A. \{pavlou@temple.edu\}

\section{Ghiyoung Im}

Computer Information Systems, College of Business, University of Louisville, Louisville, KY 40292 U.S.A. \{ghiyoung@gmail.com\}

\section{Steve Du}

Center for Process Innovation, Robinson College of Business, Georgia State University, Atlanta, GA 30303 U.S.A. \{steve.du@zoho.com\}

\section{Appendix A}

\section{Description of Measures ${ }^{1}$}

\section{KDM Archives}

The supplier used a third-party market research firm to collect data from key decision makers (KDMs) about their firm's relationship with the logistics supplier. The supplier targeted KDMs using a random sample of about 1 percent (approximately 3,000 buyers) across industries, relationship duration, and revenues of its large base of active buyers that were supported by an account executive at the supplier firm and that had a minimum threshold of shipping activity of at least one package per week or at least $\$ 10,000$ in annual revenues (to be considered a significant logistics relationship). The representative market research firm was provided an interview guide and contacted the KDMs by telephone to collect data on the following variables:

Share of wallet (DV):

What proportion of your current year's outsourced logistics budget was allocated to [SUPPLIER]?

Buyer Loyalty to Supplier (DV, Cronbach's alpha $=0.82)$

Mean of the following three items:

1. On a scale where 1 means "not at all loyal" and 10 means "completely loyal," please rate how loyal you are to [SUPPLIER].

2. On a scale where 1 means "completely disagree," and 10 means "completely agree," please rate this statement: "I am comfortable enough with [SUPPLIER] that I do not seriously consider offers from other companies."

\footnotetext{
${ }^{1}$ We do not include the name of the supplier or the names of the logistics systems for confidentiality reasons.
} 
3. On a scale where 1 means "not at all recommend" and 10 means "very highly recommend," please rate how likely you would be to recommend [SUPPLIER] to your business associates?

Buyer satisfaction with supplier (Control, Cronbach's alpha $=0.85)$

Mean of the following three items:

1. On a 0-100 scale, where 0 means you are "not at all satisfied," and 100 means you are "completely satisfied," how satisfied are you with [SUPPLIER]?

2. On a 1-10 scale, where 1 means "much worse than expected," and 10 means "much better than expected," compared to your expectations, what score would you give based on your experiences with [SUPPLIER]?

3. On a 1-10 scale, where 1 means "very far from the ideal" and 10 means "very close to the ideal," thinking about the ideal supplier for logistics, how close would you say [SUPPLIER] comes to the ideal?

Buyer size (Control):

How many employees are there in your organization?

Buyer's total logistics spending (Control):

What is your total outsourced logistics spending in the current year?

Quality of servicing IT assets (Control):

On a scale of 1-10, where 1 means "terrible" and 10 means "excellent," please rate the [SUPPLIER] in terms of servicing its IT applications and hardware that are used for your logistics processes.

Problem incidence (Control) $(\mathrm{n}=2,058)$ :

Have you had a problem with [SUPPLIER] in the past 12 months? $(1=$ Yes, $2=$ No $)$

We were able to obtain information from the vendor's KDM archives on the following three measures for a subsample of relationships, and correlated each of them with the frequency of communication with account executives and IT executives:

*Customer's satisfaction with the vendor's problem resolution $($ scale: $1=$ terrible, $10=$ excellent $)($ Cronbach's alpha $=0.85)(n=383)$

1. Being accountable when there is a problem

2. Taking care of the problem as quickly as possible

3. Doing everything they can to solve issues

*Frequency of problems experienced (Scale: $1=$ Never, $2=1-2,3=3-5,4=$ more than 5$)(n=163)$

How many times have you experienced problems in package handling in the last 12 months?

${ }^{*}$ Contact for a problem (Scale: $0=$ Account Executive, $1=$ Other $)(n=1103)$

When you have a problem with [SUPPLIER] who do you call?

Note: *These three variables were used in post hoc analysis to examine the relationship between problem incidence and problem resolution satisfaction with strategic communications with account executives.

\section{Technology Archives}

Interfirm IT Capability Profile (IV): Profile of IT capabilities in the previous year

The supplier's technology archives maintained a transaction log on the IT systems that had been implemented for each buyer. We obtained the technology archive for the previous year so that we could determine the set of IT functionalities that were implemented and used in each relationship, enabling us to classify a relationship to an interfirm IT capability profile. Toward this end, we developed and validated a coding scheme ("Measures" subsection and Table 5) that we applied to determine the set of IT functionalities that had been implemented and were being used in an interfirm relationship and to classify a relationship into one of the four interfirm IT capability profiles.

IT Utilization (Control):

Percentage of the buyer's logistics transactions with the supplier executed using the implemented set of IT functionalities 


\section{CRM Archives}

The vendor maintains a CRM system with information on its buyers, including the date when the account was created, the buyer's industry, and contacts between its account and IT executives with its buyers. The individuals at the supplier side who interact with the buyers are required to log site visits and phone calls in the CRM system with any notes pertaining to each contact. We were able to obtain summary information on the frequency of contact in terms of site visits and phone calls by account executives and by IT executives to develop the following measures:

Interfirm communications for business development (IV): Total number of visits and phone calls in past year between the supplier's account executives and the buyer

Interfirm communications for IT development (IV): Total number of visits and phone calls in past year between the supplier's IT executives and the buyer

Relationship duration (Control): Time (in years) since the account was created

Buyer industry (Control): Dummy variables based on NAICS code

\section{Financial Archives}

We obtained archival data on transaction volume and revenues for all buyers to determine the following measures:

Supplier dependence on buyer (Control): Buyer revenue for previous year/total revenue for previous year

Transaction volume (Control): Total volume of shipments for previous year (weekly data in archives) 


\section{Appendix B}

\section{Robustness Analysis Using Alternative Scaling of IT Capability Profile Sophistication}

We conducted a robustness test by scaling interfirm IT capability profile sophistication as a rank-ordered variable $(\mathrm{X}=\mathrm{ITCapSoph})$ that ranges from 1 (IT Capability Profile A) to 4 (IT Capability Profile D). The pattern of the main effects of both IT capability profile sophistication and interfirm communications as well as their interaction effects using the rank-ordered coding are qualitiatively similar to those reported in the paper using the profile coding. As such, we arrive at the same conclusions on the hypotheses supported regardless of the approach used to code IT capability profile sophistication (four profiles or rank-ordered), with the profile approach reported in the main paper providing richer insights on the differences in the main effects as well as in the interaction effects across the four IT capability profiles.

\begin{tabular}{|c|c|c|c|c|c|c|c|c|}
\hline \multirow{2}{*}{$\begin{array}{lr} & \text { Variable } \\
\text { Intercept } & \end{array}$} & \multicolumn{2}{|c|}{ Model 1a } & \multicolumn{2}{|c|}{ Model 2a } & \multicolumn{2}{|c|}{ Model 3a } & \multicolumn{2}{|c|}{ Model 4a } \\
\hline & $81.55^{\star *}$ & $(3.37)$ & $81.32^{* \star}$ & (3.35) & $81.05^{\star \star}$ & (3.35) & $81.07^{* \star}$ & (3.36) \\
\hline \multicolumn{9}{|l|}{ Controls } \\
\hline Buyer Firm Size & $-2.66^{\star *}$ & $(0.42)$ & $-2.75^{\star \star}$ & $(0.42)$ & $-2.76^{\star \star}$ & $(0.42)$ & $-2.76^{\star *}$ & $(0.42)$ \\
\hline Buyer Logistics Spending & $-2.38^{\star \star}$ & $(0.41)$ & $-2.69^{\star \star}$ & $(0.43)$ & $-2.63^{* x}$ & $(0.43)$ & $-2.63^{* \star}$ & $(0.43)$ \\
\hline Supplier's Buyer Dependence & $2161^{* \star}$ & $(670)$ & $1749^{\star \star}$ & $(686)$ & $1660^{\star \star}$ & $(687)$ & $1682^{\star \star}$ & $(693)$ \\
\hline Quality of Servicing IT Assets & $1.69^{\star \star}$ & $(0.37)$ & $1.67^{\star \star}$ & $(0.36)$ & $1.68^{\star \star}$ & $(0.36)$ & $1.68^{\star \star}$ & $(0.36)$ \\
\hline Relationship Duration & 0.00 & $(0.12)$ & 0.00 & $(0.12)$ & 0.01 & $(0.12)$ & 0.01 & $(0.12)$ \\
\hline Incidence of Problem & -0.95 & (1.48) & -0.62 & (1.47) & -0.61 & (1.47) & -0.62 & (1.47) \\
\hline Buyer Satisfaction & $0.21^{* *}$ & $(0.05)$ & $0.22^{\star \star}$ & $(0.05)$ & $0.21^{* \star}$ & $(0.05)$ & $0.21^{* \star}$ & $(0.05)$ \\
\hline IT Utilization & $4.40^{* *}$ & $(1.85)$ & $3.97^{*}$ & $(1.86)$ & $4.04^{*}$ & $(1.85)$ & $4.03^{*}$ & $(1.86)$ \\
\hline NAICS Sector 31-33 & 0.38 & $(1.60)$ & 0.22 & $(1.59)$ & 0.24 & $(1.59)$ & 0.24 & $(1.59)$ \\
\hline NAICS Sector 42-49 & 1.16 & $(1.55)$ & 1.19 & (1.55) & 1.10 & $(1.55)$ & 1.10 & $(1.55)$ \\
\hline NAICS Sector 51-56 & -0.83 & $(2.12)$ & -0.85 & $(2.11)$ & -0.85 & $(2.11)$ & -0.85 & $(2.11)$ \\
\hline \multicolumn{9}{|l|}{ Main Effects } \\
\hline $\begin{array}{l}\text { Interfirm Communications } \\
\text { for Business Development (ICBD) }\end{array}$ & & & -0.25 & $(0.72)$ & -0.26 & $(0.72)$ & -0.27 & $(0.72)$ \\
\hline $\begin{array}{l}\text { Interfirm Communications } \\
\text { for IT Development (ICTD) }\end{array}$ & & & $1.46^{*}$ & $(0.88)$ & $1.41^{+}$ & $(0.88)$ & $1.42^{*}$ & $(0.88)$ \\
\hline $\begin{array}{l}\text { IT Capability Profile Sophistication } \\
\text { (ITCapSoph) }\end{array}$ & & & $3.93^{\star \star}$ & $(1.09)$ & $3.70^{* \star}$ & $(1.09)$ & $3.73^{\star \star}$ & $(1.10)$ \\
\hline \multicolumn{9}{|l|}{ Interaction Effects } \\
\hline ICBD $\times$ ITCapSoph & & & & & $2.02^{*}$ & $(1.02)$ & $2.10^{*}$ & $(1.07)$ \\
\hline ICTD ×ITCapSoph & & & & & & & -0.37 & $(1.48)$ \\
\hline Adjusted $R^{2}$ & \multicolumn{2}{|c|}{0.096} & \multicolumn{2}{|c|}{0.104} & \multicolumn{2}{|c|}{0.105} & \multicolumn{2}{|c|}{0.105} \\
\hline Adjusted $R^{2}$ diff. & & & \multicolumn{2}{|c|}{$0.007^{\star \star}$} & \multicolumn{2}{|c|}{$0.001^{*}$} & \multicolumn{2}{|c|}{-} \\
\hline
\end{tabular}

$\mathrm{N}=1659 . \quad\left({ }^{+} p<0.10,{ }^{*} p<0.05,{ }^{* *} p<0.01\right)$

tUnstandardized coefficients (standard errors) are shown (one-tailed).

${ }^{\ddagger}$ When predictor $(X)$ and moderator $(Z)$ are correlated, the interaction term $(X \cdot Z)$ can be confounded with unmeasured nonlinear terms $\left(X^{2}\right)(C a r t e$ and Russell 2003; Cortina 1993). In our sample, the correlations between ICBD and ICTD and the predictor (IT Capability Profile Sophistication) are low or insignificant, making such a confound a very unlikely scenario. However, to ensure the robustness of our findings, we evaluated the moderation models after including the squared terms of the predictor $\left(\mathrm{X}^{2}\right)$ as a covariate, and obtained similar results to those reported in the table above. 


\begin{tabular}{|c|c|c|c|c|}
\hline Variable & Model 1b & Model 2b & Model 3b & Model 4b \\
\hline Intercept & $8.11^{\star *} \quad(0.19)$ & $8.11^{* *} \quad(0.19)$ & $8.12^{\star \star} \quad(0.19)$ & $8.12^{\star \star}$ \\
\hline \multicolumn{5}{|l|}{ Controls } \\
\hline Buyer Firm Size & $-0.06^{* *} \quad(0.02)$ & $-0.06^{* *} \quad(0.02)$ & $-0.06^{\star *} \quad(0.02)$ & $-0.06^{\star \star}$ \\
\hline Buyer Logistics Spending & -0.01 & $(0.02)$ & $(0.02)$ & -0.03 \\
\hline Supplier's Buyer Dependence & $53.31^{+} \quad(37.7)$ & $(38.7)$ & $\begin{array}{ll}33.65 & (38.7)\end{array}$ & 33.31 \\
\hline Quality of Servicing IT Assets & $0.11^{* *} \quad(0.02)$ & $0.11^{* *} \quad(0.02)$ & $0.11^{\text {**}} \quad(0.02)$ & $0.11^{* *}$ \\
\hline Relationship Duration & $(0.01)$ & $(0.01)$ & $(0.01)$ & $(0.01)$ \\
\hline Incidence of Problem & $(0.08)$ & $0.20^{\star *}$ & $\begin{array}{ll}0.20^{* *} \quad(0.08) \\
\end{array}$ & $\begin{array}{ll}0.20^{* *} & (0.08)\end{array}$ \\
\hline Buyer Satisfaction & $0.08^{* *} \quad(0.00)$ & $0.08^{\star *} \quad(0.00)$ & $0.08^{* *} \quad(0.00)$ & $0.08^{* *}$ \\
\hline IT Utilization & $(0.10)$ & $(0.10)$ & $(0.10)$ & $(0.10)$ \\
\hline NAICS Sector 31-33 & $\begin{array}{ll}0.12^{+} & (0.09)\end{array}$ & $(0.09)$ & $(0.09)$ & $(0.09)$ \\
\hline NAICS Sector 42-49 & $(0.09)$ & $(0.09)$ & $(0.09)$ & $(0.09)$ \\
\hline NAICS Sector 51-56 & $0.24^{*} \quad(0.12)$ & $(0.12)$ & $(0.12)$ & $(0.12)$ \\
\hline \multicolumn{5}{|l|}{ Main Effects } \\
\hline $\begin{array}{l}\text { Interfirm Communications } \\
\text { for Business Development (ICBD) }\end{array}$ & & $(0.04)$ & $(0.04)$ & -0.03 \\
\hline $\begin{array}{l}\text { Interfirm Communications } \\
\text { for IT Development(ICTD) }\end{array}$ & & $0.13^{\star *} \quad(0.05)$ & $0.14^{* *} \quad(0.05)$ & $0.14^{\star *} \quad(0.05)$ \\
\hline $\begin{array}{l}\text { IT Capability Profile Sophistication } \\
\text { (ITCapSoph) }\end{array}$ & & $(0.06)$ & $(0.06)$ & $(0.06)$ \\
\hline \multicolumn{5}{|l|}{ Interaction Effects } \\
\hline ICBD × ITCapSoph & & & $(0.06)$ & -0.05 \\
\hline ICTD $\times$ ITCapSoph & & & & $(0.08)$ \\
\hline Adjusted $R^{2}$ & 0.412 & 0.415 & 0.414 & 0.414 \\
\hline Adjusted $R^{2}$ diff. & & $0.003^{* *}$ & - & - \\
\hline
\end{tabular}

$\mathrm{N}=1650 .\left({ }^{+} p<0.10,{ }^{*} p<0.05,{ }^{* *} p<0.01\right)$

tUnstandardized coefficients (standard errors) are shown (one-tailed).

\section{References}

Carte, T. A., and Russell, C. J. 2003. "In Pursuit of Moderation: Nine Common Errors and Their Solutions," MIS Quarterly (27:3), pp. 479-501.

Cortina, J. M. 1993. "Interaction, Nonlinearity, and Multicollinearity: Implications for Multiple Regression,” Journal of Management (19:4), pp. $915-922$. 